\title{
The importance of Asia as a source of black carbon to the European Arctic during springtime 2013
}

\author{
D. Liu ${ }^{1}$, B. Quennehen ${ }^{2, a}$, E. Darbyshire ${ }^{1}$, J. D. Allan ${ }^{1,3}$, P. I. Williams ${ }^{1,3}$, J. W. Taylor ${ }^{1}$, S. J.-B. Bauguitte ${ }^{4}$, \\ M. J. Flynn ${ }^{1}$, D. Lowe ${ }^{1}$, M. W. Gallagher ${ }^{1}$, K. N. Bower ${ }^{1}$, T. W. Choularton ${ }^{1}$, and H. Coe ${ }^{1}$ \\ ${ }^{1}$ School of Earth, Atmospheric and Environmental Science, University of Manchester, Manchester, UK \\ ${ }^{2}$ Sorbonne Universités, UPMC Univ. Paris 06; Université Versailles St-Quentin; CNRS/INSU, \\ LATMOS-IPSL, Paris, France \\ ${ }^{3}$ National Centre for Atmospheric Science, University of Manchester, Manchester, UK \\ ${ }^{4}$ Facility for Airborne Atmospheric Measurements (FAAM), Building 125, Cranfield University, Cranfield, \\ Bedford, MK43 0AL, UK \\ ${ }^{a}$ now at: Univ. Grenoble Alpes/CNRS, Laboratoire de Glaciologie et Géophysique de l'Environnement (LGGE), \\ 38041 Grenoble, France
}

Correspondence to: D. Liu (dantong.liu@manchester.ac.uk)

Received: 7 May 2015 - Published in Atmos. Chem. Phys. Discuss.: 27 May 2015

Revised: 12 October 2015 - Accepted: 14 October 2015 - Published: 20 October 2015

\begin{abstract}
Black carbon aerosol (BC) deposited to the Arctic sea ice or present in the free troposphere can significantly affect the Earth's radiation budget at high latitudes yet the $\mathrm{BC}$ burden in these regions and the regional source contributions are poorly constrained. Aircraft measurements of aerosol composition in the European Arctic were conducted during the Aerosol-Cloud Coupling And Climate Interactions in the Arctic (ACCACIA) campaign in March 2013. Pollutant plumes were encountered throughout the lower to upper Arctic troposphere featuring enhancements in $\mathrm{CO}$ and aerosol mass loadings, which were chemically speciated into $\mathrm{BC}$ and non-refractory sulphate and organic matter. FLEXPART-WRF simulations have been performed to evaluate the likely contribution to the pollutants from regional ground sources. By combining up-to-date anthropogenic and open fire biomass burning (OBB) inventories, we have been able to compare the contributions made to the observed pollution layers from the sources of eastern/northern Asia (AS), Europe (EU) and North America (NA). Over $90 \%$ of the contribution to the $\mathrm{BC}$ was shown to arise from non-OBB anthropogenic sources.

AS sources were found to be the major contributor to the $\mathrm{BC}$ burden, increasing background $\mathrm{BC}$ loadings by a factor of 3-5 to $100.8 \pm 48.4 \mathrm{ng} \mathrm{sm}^{-3}$ (in standard air $\mathrm{m}^{3}$ at $273.15 \mathrm{~K}$ and $1013.25 \mathrm{mbar}$ ) and $55.8 \pm 22.4 \mathrm{ng} \mathrm{sm}^{-3}$ in
\end{abstract}

the middle and upper troposphere respectively. AS plumes close to the tropopause (about 7.5-8 km) were also observed, with $\mathrm{BC}$ concentrations ranging from 55 to $73 \mathrm{ng} \mathrm{sm}^{-3}$, which will potentially have a significant radiative impact. EU sources influenced the middle troposphere with a BC mean concentration of $70.8 \pm 39.1 \mathrm{ng} \mathrm{sm}^{-3}$ but made a minor contribution to the upper troposphere due to the relatively high latitude of the source region. The contribution of NA was shown to be much lower at all altitudes with $\mathrm{BC}$ mean concentration of $20 \mathrm{ng} \mathrm{sm}^{-3}$. The BC transported to the Arctic is mixed with a non-BC volume fraction representing between $90-95 \%$ of the mass, and has a relatively uniform core size distribution with mass median diameter 190-210 $\mathrm{nm}$ and geometric standard deviation $\sigma_{\mathrm{g}}=1.55-1.65$ and this varied little across all source regions. It is estimated that $60-95 \%$ of $\mathrm{BC}$ is scavenged between emission and receptor based on $\mathrm{BC} / \triangle \mathrm{CO}$ comparisons between source inventories and measurement.

We show that during the springtime of 2013, the anthropogenic pollution particularly from sources in Asia, contributed significantly to $\mathrm{BC}$ across the European Arctic free troposphere. In contrast to previous studies, the contribution from open wildfires was minimal. Given that Asian pollution is likely to continue to rise over the coming years, it is likely 
that the radiative forcing in the Arctic will also continue to increase.

\section{Introduction}

The Arctic is one of the most sensitive regions in the world to climate change (IPCC, 2014). It is warming more rapidly than anywhere else on Earth and is subject to various forcing and feedback processes such as black carbon deposition and albedo reduction (Flanner et al., 2007), increase of low-level atmospheric heating over high albedo surfaces (Pueschel and Kinne, 1995) and the increase of cloud longwave emissivity (Garret and Zhao, 2006). The Arctic Haze phenomenon in springtime has been regularly reported and is associated with high levels of gaseous and aerosol air pollutants (e.g. Greenaway, 1950). The low surface temperature and the diabatic cooling in the Arctic region during winter and early spring can lead to a thermally stable stratification - the so called Arctic Dome (Klonecki et al., 2003), where the inversion layer tends to trap the pollutants and form a barrier at the top of the atmospheric surface layer.

Although black carbon (BC) is a relatively small mass fraction of aerosol in the Arctic compared to organic matter and sulphate (Quinn et al., 2002), it affects the radiative balance by efficient absorption of shortwave radiation in the free troposphere (Bond et al., 2013) as well as its deposition on the snow, which decreases the surface albedo and promotes melting (Hansen and Nazarenko, 2004). Measurements of $\mathrm{BC}$ in the past decade have been intensively conducted at various Arctic surface stations including many long-term studies (e.g. Polissar et al., 1999; Sharma et al., 2004, 2006; Stohl et al., 2007; Shaw et al., 2010; Yttri et al., 2014). In these studies, BC from polluted regions was consistently observed to be transported from outside of the Arctic and built up in the Arctic boundary layer during winter and/or spring time. Anthropogenic fossil fuel (FF) sources have long been recognized as sources of $\mathrm{BC}$ transported to the Arctic (e.g. Quinn et al., 2002; Koch and Hansen, 2005; Law and Stohl, 2007), but the important contributions of open biomass burning (OBB) sources such as agriculture and boreal forest fires have also been reported (e.g. Reid et al., 2005; Quinn et al., 2007, and references therein). The overall relative importance of FF and OBB influences is currently uncertain.

Surface measurements of aerosols are however not necessarily representative of the overall troposphere, and this is particularly the case for the Arctic because of the strong stratification (Klonecki et al., 2003). The BC transported to the Arctic free troposphere may have been transported through a different route compared to the $\mathrm{BC}$ in the boundary layer and the high-altitude troposphere is more likely to be influenced by the sources further south (Koch and Hansen, 2005; Stohl, 2006; Hirdman et al., 2010). The emissions in Eastern/Northern Asia have grown rapidly in the past 2 decades and many studies have pointed out that this region may have a significant impact on the Arctic BC concentration in late winter and early spring time, especially in the free troposphere (Koch and Hansen, 2005; Shindell et al., 2008; Wang et al., 2011; Shaw et al., 2010; Frossard et al., 2011). The meridional transport to the Arctic during springtime could also be important (Shaw et al., 2010; Marelle et al., 2015; Raatikainen et al., 2015). This long-range transport may be facilitated by warm conveyor belts (WCBs) (Eckhardt et al., 2004) when air parcels can be vertically uplifted in the free troposphere before being transported to the Arctic (Koch and Hansen, 2005; Stohl, 2006).

The impact of open biomass burning sources in BC concentrations in the Arctic has been increasingly emphasized during the recent ARCTAS (Jacob et al., 2010) and ARCPAC (Brock et al., 2011) campaigns in springtime 2008. The intensive agricultural burning in Eastern Europe (Stohl et al., 2007) as well as the boreal forest fires in Siberia (e.g. Warneke et al., 2009) largely contributed to the Arctic BC burden in the 2008 Arctic springtime. These sources are at high-latitude locations and thus their emissions tend to follow low-level quasi-isentropic transport to the Arctic and influence the Arctic lower/middle troposphere (Stohl, 2006). Compared to the lower-latitude sources, these sources had likely undergone less wet scavenging. The OBB plumes observed in these studies were throughout the lower to higher Alaskan Arctic troposphere, featuring with higher loadings of particulate organic matter than sulphate (e.g. Brock et al., 2011; Warneke et al., 2009; Matsui et al., 2011). These studies all consistently reported the $\mathrm{BC}$ from the remote Asian fossil fuel sources were significantly scavenged (e.g. Stohl, 2006; Matsui et al., 2011), and hereinafter concluded a more significant influence of OBB sources than fossil fuel for that time of the year.

The concentration of $\mathrm{BC}$ in the Arctic is poorly represented by models (Quinn et al., 2007; Koch et al., 2009, and references therein). It has been widely reported that the measured vertical BC profiles in the Arctic show large diversity among models but almost all models underestimate $\mathrm{BC}$ throughout the lower and middle troposphere (e.g. Lee et al., 2013, and references therein), whereas some of the models overestimate $\mathrm{BC}$ in the upper troposphere and lower stratosphere (Koch et al., 2009). Many models show the scavenging parametrization could fundamentally lead to model bias. A seasonal variation in the wet scavenging mechanism (e.g. J. Liu et al., 2011; Bourgeois and Bey, 2011; Browse et al., 2012; Hodnebrog et al., 2014; Myhre and Samset, 2015) has shown considerably improved comparison with measurements by extending the lifetime of $\mathrm{BC}$ in the spring/wintertime, largely because during the cold season ice clouds result in a less efficient nucleation scavenging efficiency compared to warm clouds. An extended BC lifetime in cold seasons and a seasonally dependent $\mathrm{BC}$ removal system are thus suggested for these models. However to extend the $\mathrm{BC}$ lifetime may at the same time exacerbate 
model overestimates of $\mathrm{BC}$ mass at higher altitudes (Lund and Berntsen, 2012). The scavenging mechanism of $\mathrm{BC}$ is source and meteorologically dependent at different levels of Arctic troposphere and improved understanding of BC scavenging efficiency is desired to evaluate model outputs.

Aircraft measurements of aerosol and gaseous pollutants including $\mathrm{BC}$, sulphate, organic matter and $\mathrm{CO}$ were conducted during the Aerosol-Cloud Coupling And Climate Interactions in the Arctic (ACCACIA) campaign in springtime 2013. Plumes from Eastern/Northern Asia, Europe and North America were encountered at different levels in the European Arctic troposphere. Lagrangian dispersion models combined with up-to-date emission inventories are used to evaluate the source origins for the observed plumes. The statistics of plumes and vertical profiles under classified source regions are analysed to determine the influences of different source regions as a function of altitude throughout the Arctic troposphere. Finally, the scavenging efficiency of $\mathrm{BC}$ is estimated by comparing the inventory and measured $\mathrm{BC} /$ excess $\mathrm{CO}$ ratio.

\section{Measurements}

The flights took place during March-April 2013 as part of the Aerosol-Cloud Coupling And Climate Interactions in the Arctic (ACCACIA) project. The measurements described here were made using the UK Facility for Airborne Atmospheric Measurements (FAAM), a BAe-146 aircraft, in the region between continental Norway and Svalbard. A number of straight level runs (SLRs) and vertical profiles were performed for each flight. Figure 1 shows the flight tracks during the campaign.

The physical properties of individual refractory $\mathrm{BC}$ particles (rBC, as defined by Petzold et al., 2013) were characterized using a single particle soot photometer (SP2) manufactured by DMT Inc (Boulder, CO, USA). The instrument operation and data interpretation procedures of the specific Manchester SP2 instrument have been described elsewhere (Liu et al., 2010; McMeeking et al., 2010). The SP2 incandescence signal was calibrated for BC mass using Aquadag ${ }^{\circledR}$ black carbon particle standards (Aqueous Deflocculated Acheson Graphite, manufactured by Acheson Inc., USA) and corrected for ambient $\mathrm{BC}$ with a factor of 0.75 (Baumgardner et al., 2012). An rBC spherical equivalent core diameter $\left(D_{\mathrm{c}}\right)$ can be derived from the rBC mass and a coating thickness (the ratio of the particle diameter, $D_{\mathrm{p}}$, to the core diameter, $D_{\mathrm{p}} / D_{\mathrm{c}}$ ) may be estimated for each particle containing $\mathrm{BC}$ assuming a complete and concentric covering of the core. The methodology to determine the $D_{\mathrm{p}} / D_{\mathrm{c}}$ is detailed in Taylor et al. (2015) and Liu et al. (2014): the measured scattering cross section of coated $\mathrm{BC}$ was derived using a prescribed Mie look up table at the SP2 operational wavelength $\lambda=1064 \mathrm{~nm}$ using a core refractive index $2.26-1.26 i$ and coating refractive index $1.50+0 i$, and the uncertainty of

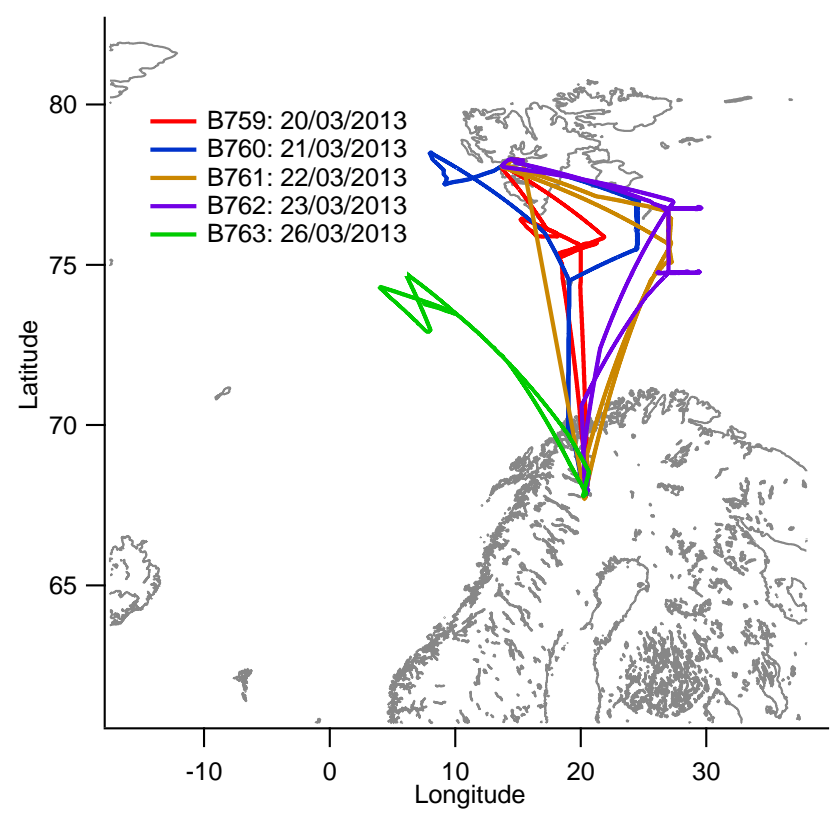

Figure 1. Flight tracks during ACCACIA spring campaign.

the derived $D_{\mathrm{p}} / D_{\mathrm{c}}$ due to particle geometry is $<6 \%$ (Liu et al., 2015).

The chemical composition of non-refractory PM1 was measured by an Aerodyne C-ToF aerosol mass spectrometer (AMS). A detailed description of the instrument can be found elsewhere (Drewnick et al., 2005). A time- and compositiondependent collection efficiency (CE) was applied to the data based on the algorithm by Middlebrook et al. (2012). It is noted that most atmospheric BC particles contain nonabsorbing material as a result of co-emission of either the particulate matter or its precursors. This additional material will be observed by the AMS. BC particles with little associated non-absorbing material may bounce and result in a reduced $\mathrm{CE}$ but the fraction of the non-refractory mass mixed with $\mathrm{BC}$ is small relative to the total non-refractory mass, and is therefore unlikely to affect the reported AMS mass loadings. An AMS-SMPS volume comparison could not be performed as we have found that the SMPS concentrations at altitude are incorrect, possibly due to an inaccuracy in the assumed charge distribution during inversion (Sakamoto et al., 2015; López-Yglesiasand and Flagan, 2013). The AMS was calibrated using mono-disperse ammonium nitrate particles. All of the SP2 and AMS measured concentrations are reported as mass concentrations at standard temperature and pressure (STP, $273.15 \mathrm{~K}$ and $1013.25 \mathrm{mbar}$ ), denoted by $\mathrm{sm}^{-3}$. Data are missing from some flights due to a malfunction of the logging computer.

Carbon monoxide was measured by an AeroLaser AL5002 VUV resonance fluorescence gas analyser, and TECO 49 UV photometric ozone instrument measured $\mathrm{O}_{3}$. In-flight $\mathrm{CO}$ calibrations were applied to the raw $\mathrm{CO}$ 

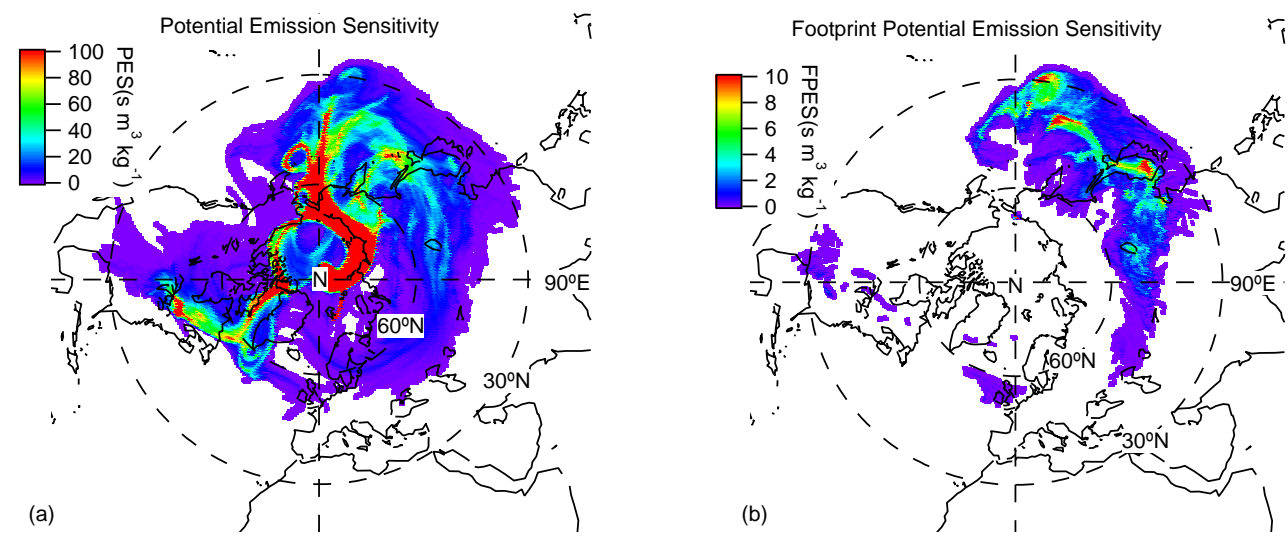

Figure 2. A typical example of (a) PES and (b) FPES from FLEXPART simulation from flight B759.

data. The background concentrations of $\mathrm{CO}$ were defined as the lowest 5th percentiles (Koike et al., 2003) for all of the data collected during the campaign. Because some of the flights in this study had reached high altitudes close to the tropopause, the $\mathrm{CO}$ background concentrations were derived as a function of altitude, as shown in the Supplement (Fig. S1). The significantly lower CO background corresponding with an enhancement of $\mathrm{O}_{3}$ at about $6 \mathrm{~km}$ may suggest a stratospheric intrusion (Thomas et al., 2013). The altitude-dependent CO background (Fig. S1d) is therefore used to calculate the excess $\mathrm{CO}$ relative to the background $(\Delta \mathrm{CO})$. This method produces consistent $\Delta \mathrm{CO}$ among flights when the sampled air masses were not significantly influenced by recognized source regions (Fig. S4b1). A background concentration of zero was assumed for BC (Matsui et al., 2011).

\section{Model simulations}

In this study, a Lagrangian particle dispersion model (FLEXPART) is applied to characterize the origin of the sampled air masses up to 12 days backward. In addition, the HYSPLIT backward trajectory model was used to interrogate the meteorological history through the pollutant transportation pathways. The back trajectories will be subject to increased model integration error when backward modelling time exceeds 5-6 days, leading to uncertainties when assigning the meteorological information to the back trajectory path, meaning that sources can only be assigned on continental scales.

\subsection{FLEXPART-WRF}

The Lagrangian particle dispersion model FLEXPART-WRF (Brioude et al., 2013), adapted from the FLEXPART model (version 6.2, Stohl et al., 2005) was used in a backward mode to characterize the origin of the sampled air masses. FLEXPART-WRF was driven by WRF meteoro-

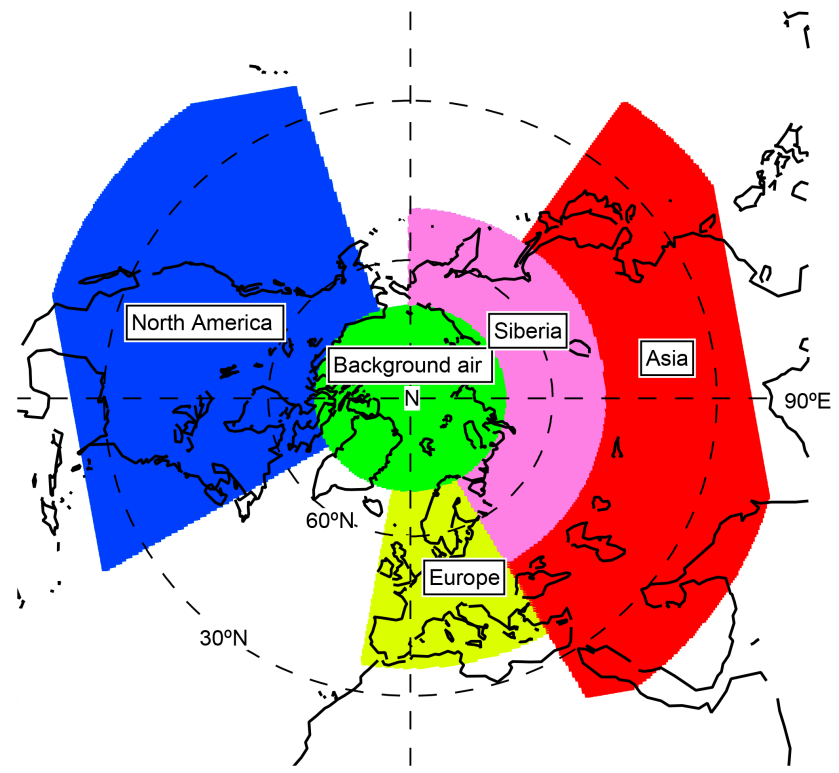

Figure 3. Source regions defined in this study.

logical forecasts and a new simulation was initialized each time the aircraft position changed by more than $0.20^{\circ}$ in latitude/longitude or $250 \mathrm{~m}$ vertically. For each simulation, 20000 particles were released in a volume $50 \times 50 \mathrm{~km}$ (horizontally) and $500 \mathrm{~m}$ (vertically), particles were tracked 12 days backward in time. The primary output of FLEXPART backward calculations is the potential emission sensitivity (PES) which expresses the residence time of particles at a given location and is used to characterize the transport pathways of the sampled air masses. A further extraction of the lowest model layer, i.e. integrated on the $0-500 \mathrm{~m}$ layer, termed as the footprint PES (FPES), is used to evaluate the air mass potential sensitivity to ground sources. Figure 2 gives a typical example of the FLEXPART outputs of PES and FPES. 


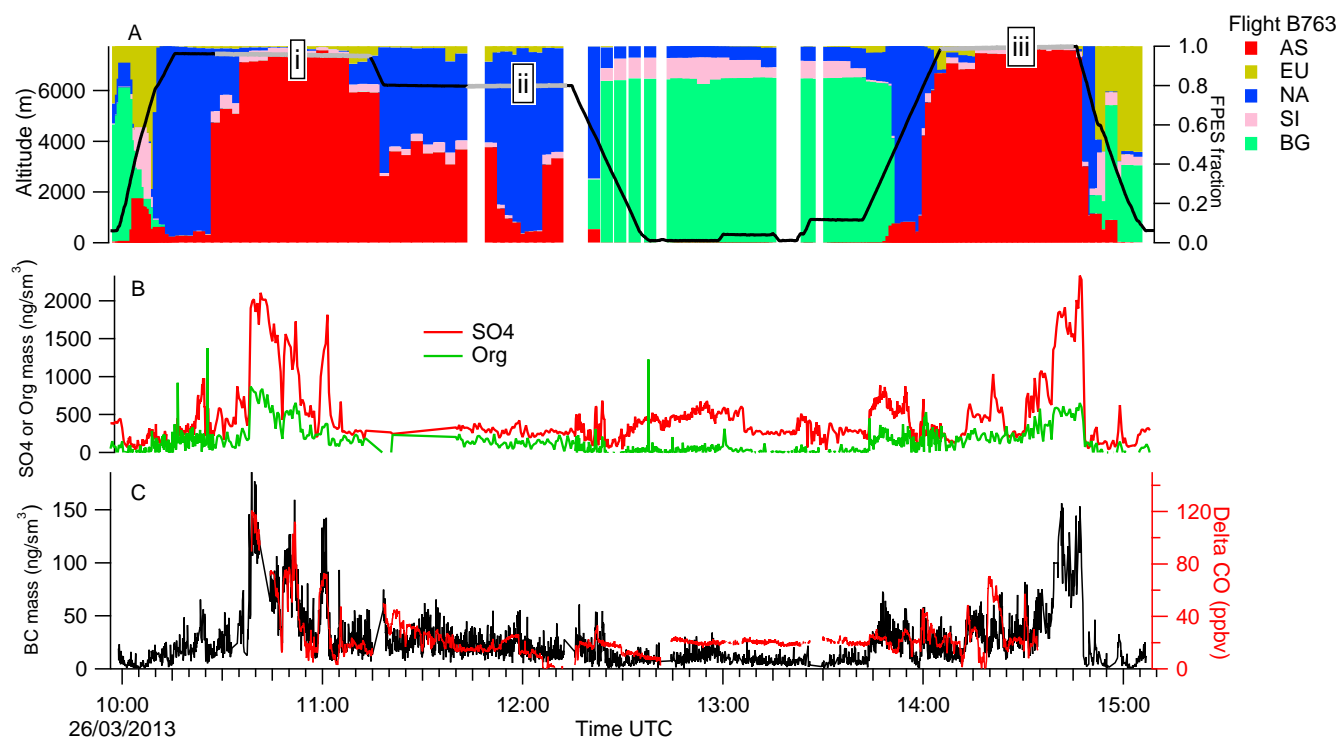

Figure 4. (a) The flight altitude and FLEXPART FPES fractions for each source region during B763, the plume locations during SLR are marked as i, ii and iii and grey lines along the flight altitude track; (b) the time series of organic matter and sulphate; (c) BC mass and CO concentration.

The relative contributions to the sampled air masses from different ground sources can be attributed by multiplying the FPES values with the source-specified inventory emissions (in $\mathrm{kg} \mathrm{m}^{-2} \mathrm{~s}^{-1}$ ). This study will focus on the $\mathrm{BC}$ and $\mathrm{CO}$ source evaluations from both anthropogenic and open biomass burning $(\mathrm{OBB})$ sources.

We have classified the major recognized ground source regions in the following way: Asia $\left(R_{\mathrm{AS}}\right)$, Europe $\left(R_{\mathrm{EU}}\right)$, North America $\left(R_{\mathrm{NA}}\right)$, Siberia $\left(R_{\mathrm{SI}}\right)$ and Background Air $\left(R_{\mathrm{BG}}\right)$, as shown in Fig. 3. The extent of each region is detailed as follows:

i. Asia $\left(R_{\mathrm{AS}}, 20-50^{\circ} \mathrm{N}, 30-145^{\circ} \mathrm{E}\right)$, including northern/eastern China, Japan and Mongolia.

ii. Europe $\left(R_{\mathrm{EU}}, 35-70^{\circ} \mathrm{N}, 10^{\circ} \mathrm{W}-30^{\circ} \mathrm{E}\right)$, corresponding to the whole of Europe.

iii. North America $\left(R_{\mathrm{NA}}, 20-50^{\circ} \mathrm{N}, 60-160^{\circ} \mathrm{W}\right)$, including USA, Canada and Mexico.

iv. Siberia $\left(R_{\mathrm{SI}}, 50-70^{\circ} \mathrm{N}, 30-180^{\circ} \mathrm{E}\right)$.

v. The Artic Background air $\left(R_{\mathrm{BG}}, 70-90^{\circ} \mathrm{N}\right)$, which is without significant continental source contact.

\subsection{HYSPLIT backward trajectories}

The HYSPLIT 4.0 model (Draxler and Hess, 1998) back trajectories were initiated from the latitude, longitude and altitude of the aircraft every $30 \mathrm{~s}$ along the flight path and calculated 14 days backward in time. Horizontal and vertical wind fields for trajectory calculations were provided by the $1^{\circ} \times 1^{\circ}, 3$-hourly GDAS 1 reanalysis meteorology (Global
Data Assimilation System; NOAA Air Resources Laboratory, Boulder, CO, USA). This also allows retrieval of potential temperature $(\theta)$ and precipitation rate along each trajectory path. The reported meteorological information extracted along the trajectory path is averaged over all of the trajectories along the flight track for the targeting time period.

\section{Results}

\subsection{Air mass origins of pollution plumes}

Plumes were encountered at various levels throughout the Arctic troposphere from $300-8000 \mathrm{~m}$ and all plumes were characterized by enhancements over the average, altitude resolved background values of $\mathrm{BC}, \mathrm{CO}$, sulphate and organic matter. The sulphate content was found to be significantly higher than the organic matter by a factor of 1.5-4. Figure 4 shows the measurement results and the FPES-derived air mass origins for the flight B763 (identical information for the other flights can be found in Fig. S2). Note that the plumes observed during straight and level runs (SLRs) for each flight are marked with Roman numerals (as shown on the flight altitude track in Fig. 4) and were analysed separately from the vertical profiles sampled during aircraft ascent and descent.

For each FLEXPART-WRF simulation, the FPES was gridded into the defined source regions (Fig. 3) along each flight track (Fig. 4a). For each FPES calculation, the air masses may have passed over multiple source regions $\left(R_{\mathrm{BG}}\right.$, $R_{\mathrm{AS}}, R_{\mathrm{EU}}, R_{\mathrm{NA}}$ and $\left.R_{\mathrm{SI}}\right)$ as defined in Fig. 3 . The air mass origin is classified as $\mathrm{BG}$ when the $R_{\mathrm{BG}}$ contributes more 

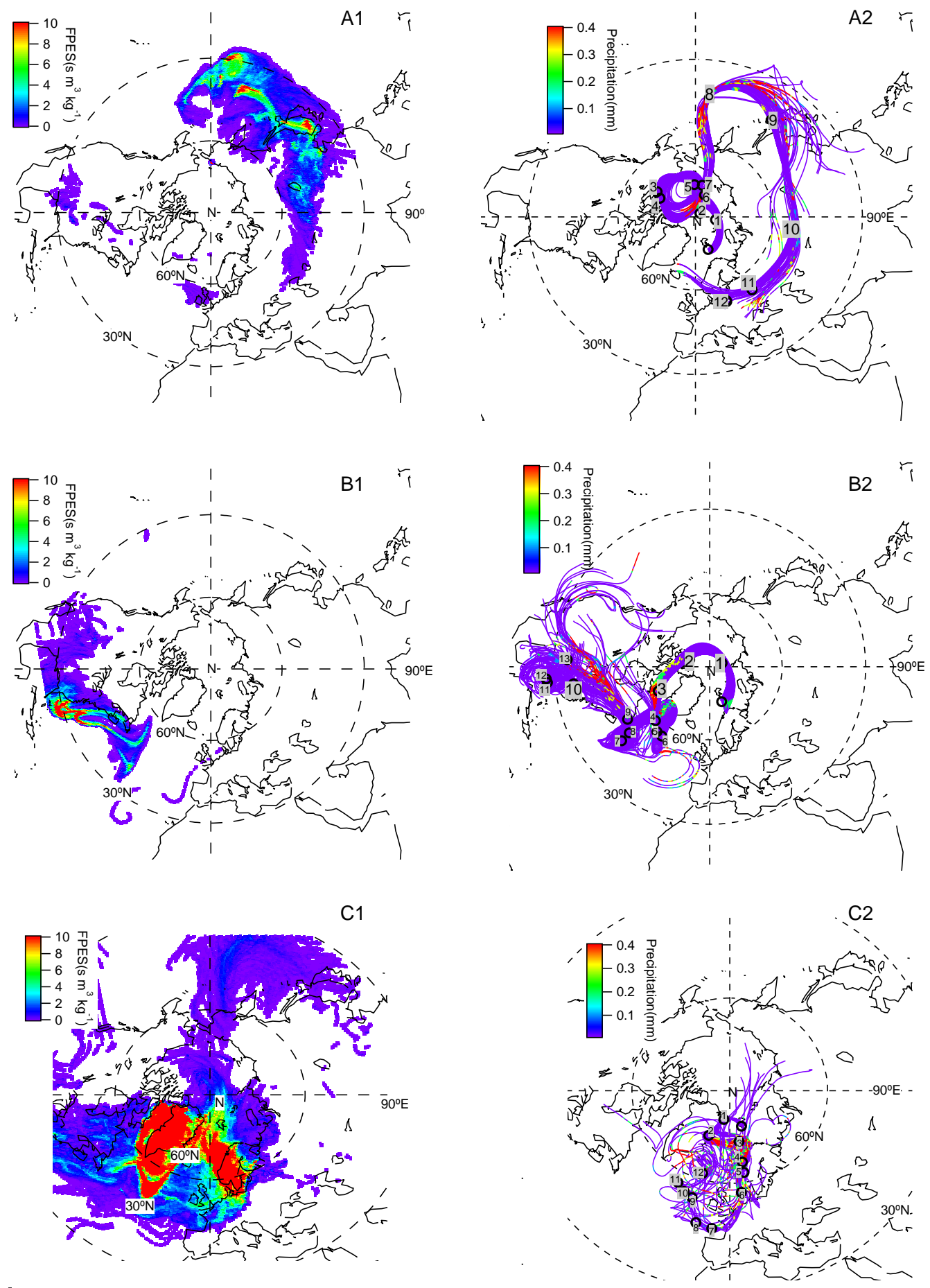

Figure 5.

than $80 \%$ of the grid-integrated total FPES. For the rest of the cases when $R_{\mathrm{BG}}$ contributes less than $80 \%$, the air mass origin is then classified according to the relative contributions of $R_{\mathrm{AS}}, R_{\mathrm{EU}}$ and $R_{\mathrm{NA}}$. The air mass will be classified as the specified source region if the relative contribution of any corresponding source region is greater than $60 \%$ of the total polluted source region contribution, for example if $R_{\mathrm{AS}} /\left(R_{\mathrm{AS}}+R_{\mathrm{EU}}+R_{\mathrm{NA}}\right)$ is $>60 \%$, the air mass is classified as AS. In some cases $R_{\mathrm{EU}}$ and $R_{\mathrm{NA}}$ both contributed more than $40 \%$, where the air mass was classified as EU + NA. The $R_{\mathrm{SI}}$ is excluded from the air mass classification because this region was found to make a minor contribution to the 

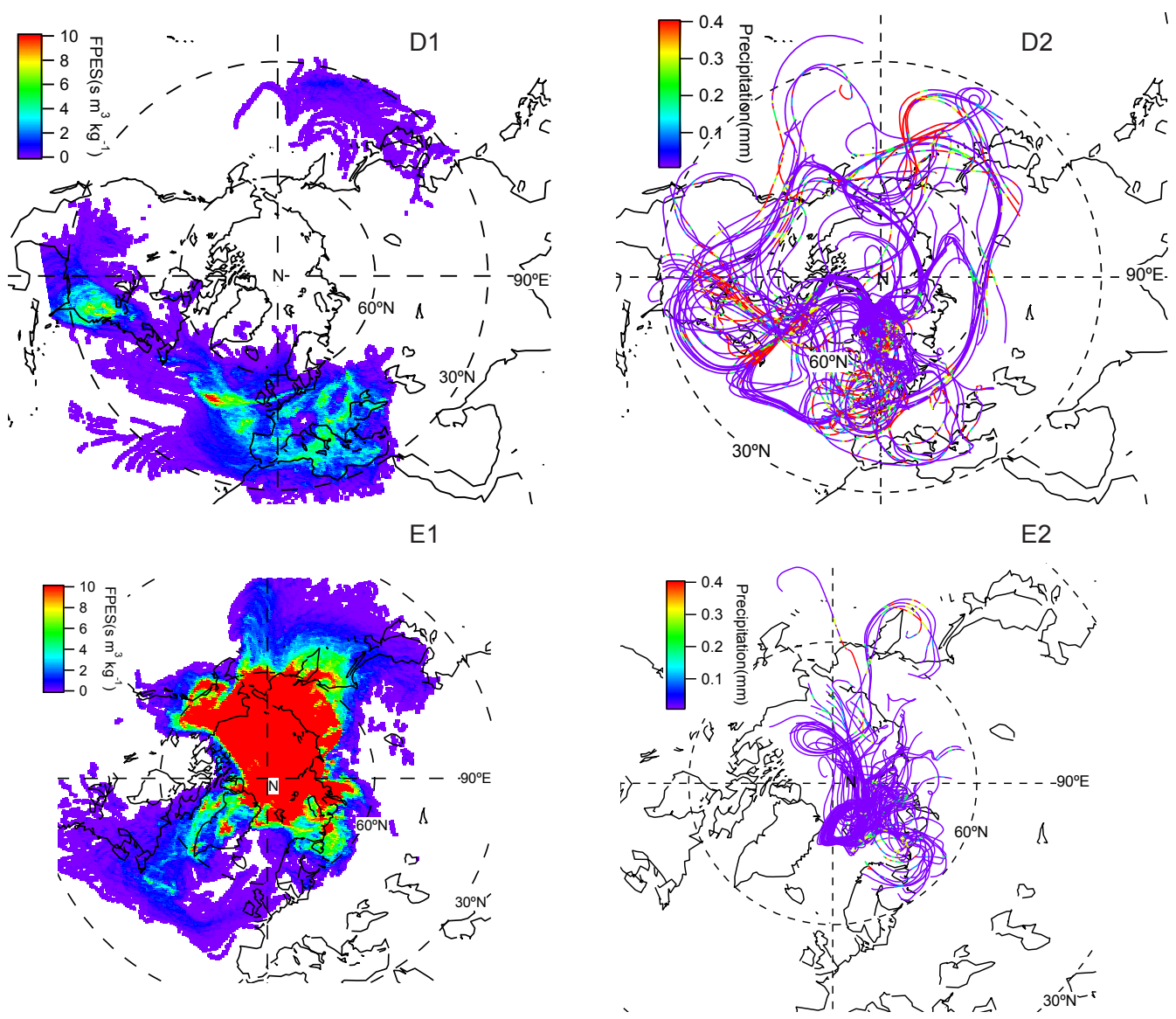

Figure 5. The FLEXPART FPES (left panels from a1-e1) and the corresponding HYSPLIT backward trajectories (right panels from a2-e2) for each classified air mass origin, representing flight B759 10:50-11:15, B760 08:45-09:45, B761 12:10-12:25, B761 15:06-15:15 and B759 15:15-15:45 respectively. Each backward trajectory is coloured by precipitation along the pathway and the open circles with numbers in panels (a2), (b2) and (c2) mark the time backwards along the trajectory in 1-day intervals.

ground sources during the time of the year according to the inventories (Sect. 4.2). This is supported by the observation that for most of the flights the contribution of $R_{\mathrm{SI}}$ to total FPES is not important (top panels in Fig. S2).

Figure 5 shows typical examples of FLEXPART-WRF FPES and the corresponding HYSPLIT backward trajectories for the plumes with each defined air mass origin. Because of the good consistency between FLEXPART and HYSPLIT model outputs, the plume age since emission can be estimated by locating the trajectories on the FPES map: the source emission starts from the backward time when the trajectories for that particular plume passed over the region that is most sensitive to the recognized ground sources, i.e. with the largest FPES values. The number of plumes and vertical profiles for each flight is summarized in Table 1.

\subsection{Attribution of plume sources}

Figure 6 shows the $\mathrm{BC}$ emission inventories as used in this study. The anthropogenic sources are classified to occur from the following sectors (Fig. S3): residential (RE), transport
(TR), industry (IN), energy (EN) and Flaring (FL). The RE, TR, IN and EN are taken from the HTAPv2 $0.1^{\circ} \times 0.1^{\circ}$ inventory for March 2010, which is the most recent available anthropogenic inventory, and the FL is from the ECLIPSE (Evaluating the CLimate and Air Quality ImPacts of ShortlivEd Pollutants) global emission inventory (Stohl et al., 2015). Comparison between the emissions inventory in 2010 and 2005 shows the BC emissions increase by less than $30 \%$. It is to be expected that any differences between 2010 and 2013 will be less than this amount.

The open biomass burning (OBB) inventory is from FINN v1 (http://bai.acd.ucar.edu/Data/fire/) (Wiedinmyer et al., 2006) for March 2013. Because the OBB emissions are based on observed fires, these have significant time variation and have been computed at 1 hour time resolution. $\mathrm{CO}$ emissions are also taken from the equivalent inventories as BC.

The total $\mathrm{BC}$ emissions from each region are shown in Fig. 7. AS is the largest source region for both anthropogenic and OBB emissions, whereas SI emissions are relatively low during that time of the year. The residential sector, largely 
Table 1. The number of vertical profiles and plumes observed for each flight.

\begin{tabular}{lll}
\hline & Number of profiles & Number of plumes \\
\hline B759 (20 March 2013) & 7AS; 1NA & 5AS; 1NA \\
B760 (21 March 2013) & 3AS; 2NA & 2AS; 2NA \\
B761 (22 March 2013) & 3EU; 1EU + NA; 1AS & 3EU; 1EU + NA; 1NA \\
B762 (23 March 2013) & 6NA & 3NA; 1EU \\
B763 (26 March 2013) & 2NA & 2AS;1NA \\
\hline
\end{tabular}
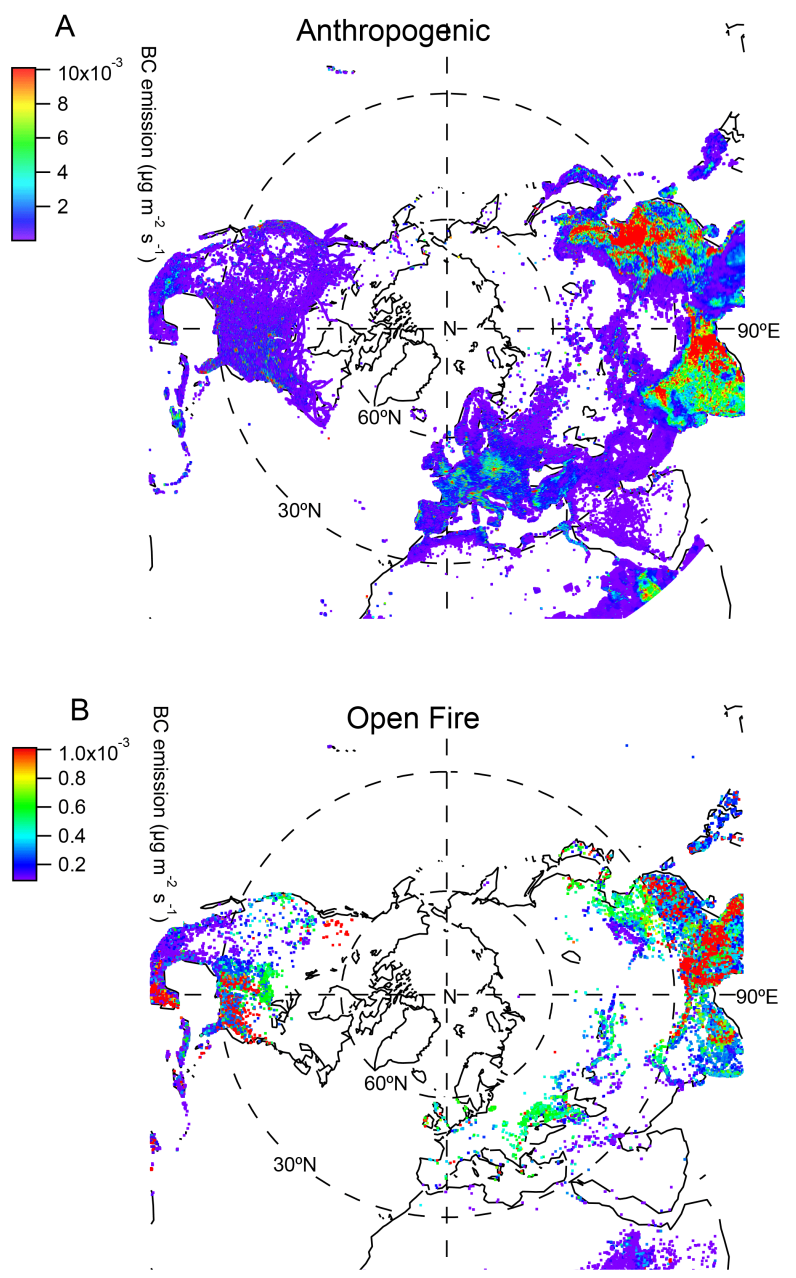

Figure 6. The BC anthropogenic (a) in March 2010 and open fire (b) emission inventories in March 2013, from HTAPv2 and the FINN open fire biomass burning inventory respectively. The specified sectors for anthropogenic sources, i.e. residential activity, transport, industry, energy and flaring are shown in Fig. S3.

domestic solid fuel burning, is the most important contributor to the total anthropogenic emissions. OBB sources show significant time variations, with higher OBB emissions from AS dominating in the first half of the month, and those from NA increasing during three short periods with high loadings of enhanced emissions, though these are approximately an

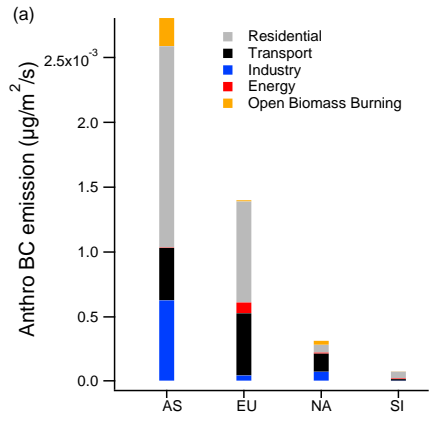

(b)

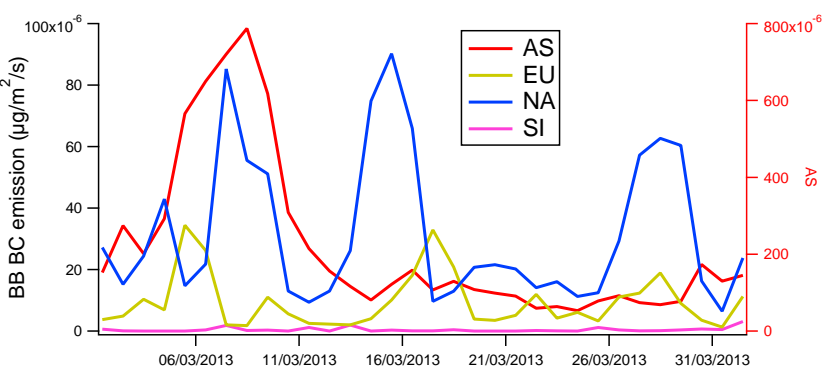

Figure 7. BC emissions characterized by source region (as defined in Fig. 2). (a) comparison between different source sectors; (b) the temporal evolution of OBB sources throughout the experimental period. Note for AS, the right axis is used.

order of magnitude smaller than the OBB emissions from NA.

The anthropogenic and OBB source contributions to the $\mathrm{BC}$ or $\mathrm{CO}$ within an air parcel were determined by multiplying the FPES by the $\mathrm{BC}$ or $\mathrm{CO}$ emission inventories at the same grid resolution (Quennehen et al., 2011, 2012). The grid-integrated FPES $\times$ inventory is interpreted as the total ground source contributions to the observed plume in the 12 days prior to measurement. The modelled source attributions (from RE, TR, IN, EN and OBB) of BC and CO for each plume are summarized in Table $\mathrm{S} 1$. The resulting contributing fractions of OBB sources to the total $\mathrm{BC}$ and $\mathrm{CO}$ are shown in the 4th and 5th column of Table 2. The plumes with sources originating from Eastern AS and NA in the first half of the month had more OBB contributions (Figs. 6b and 7b) whereas the OBB contribution was weaker when the source origins were located towards higher latitudes. The overall 


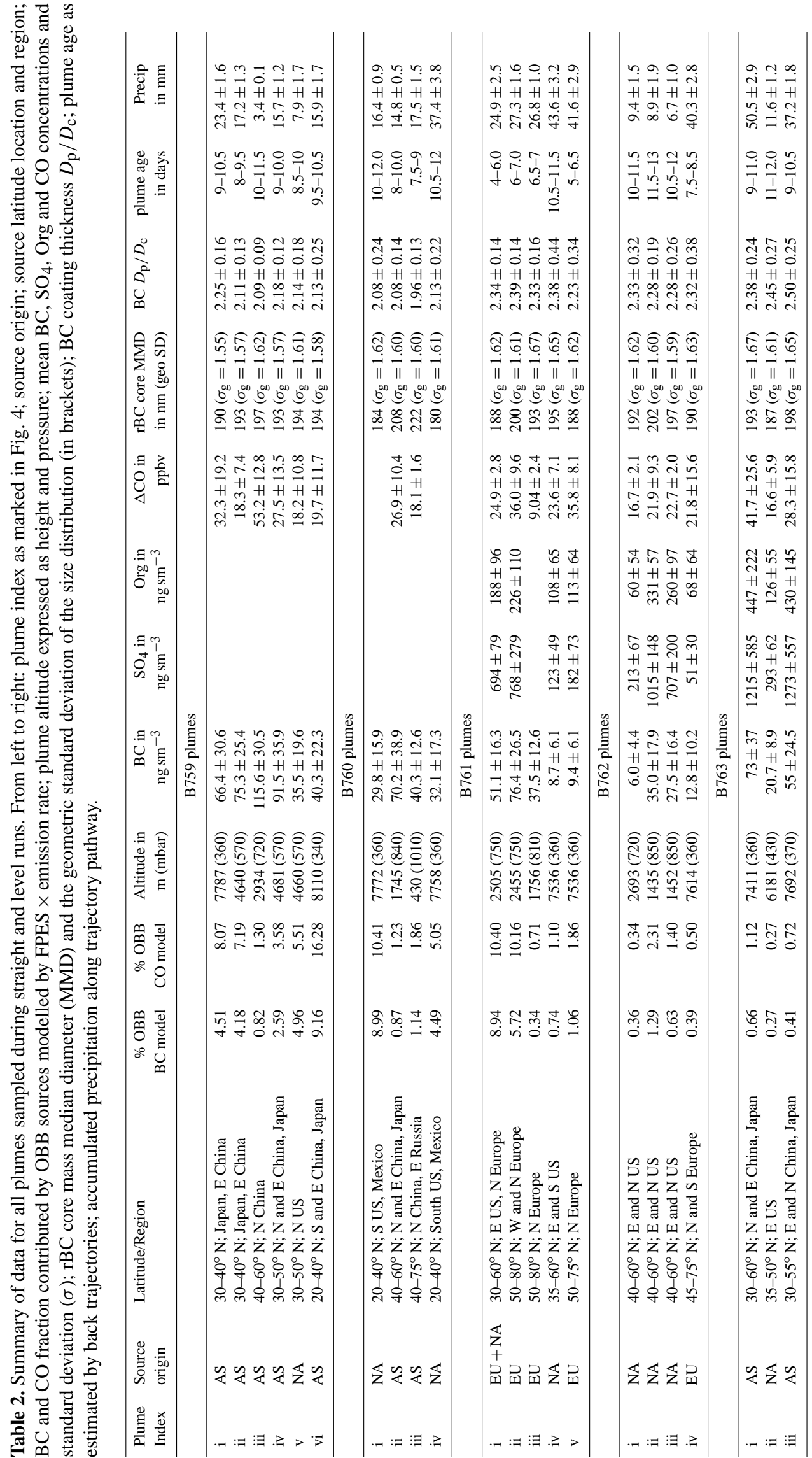



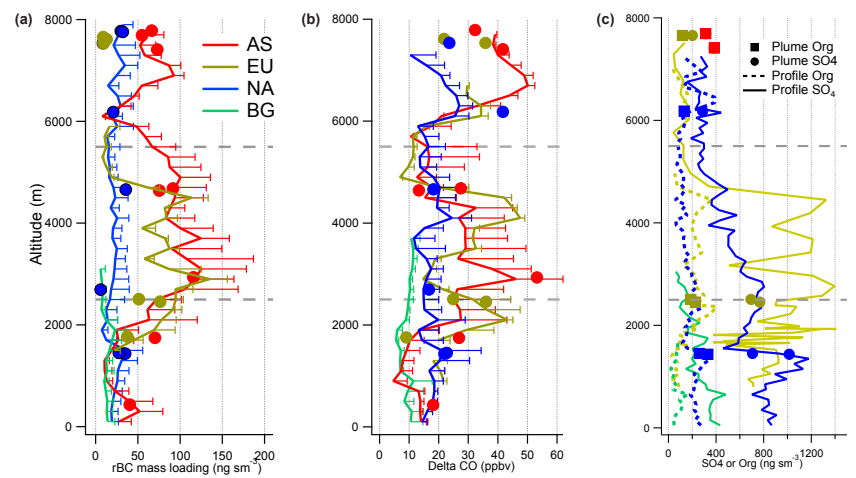

Figure 8. Vertical profiles (binned in $200 \mathrm{~m}$ altitude) and plumes classified by air mass origin: the lines show the mean values and $+\sigma$ (standard deviation) for data obtained during vertical profiles; the filled markers denote values derived during plume intercepts along straight and level runs for (a) rBC mass loading; (b) $\triangle \mathrm{CO}$; (c) sulphate and organic matter. Note there were no sulphate or organic data available for AS vertical profiles therefore only AS plume information is shown in panel (c). The horizontal dash lines on each graph show the bounds of LT/MT/UT.

OBB contribution to BC is $0.2-10$ and $0.2-16 \%$ for CO. Anthropogenic contributions therefore dominate during the experimental period, which is consistent with the observation that the particulate sulphate mass was significantly higher than that of organic matter for all plumes. In particular, flaring sources make a negligible contribution to the $\mathrm{BC}$ and $\mathrm{CO}$ loadings (of the order of $10^{2}$ or $10^{3}$ magnitude lower than the other anthropogenic contributions as shown in Table S1). This is because the plumes in this study were mainly encountered in the middle or upper troposphere and the resulting back trajectories show that there was little land contact over the high-latitude regions where flaring sources are present.

Figure S4 summarizes the plume characteristics and vertical profiles classified by air mass origin, with the mean value presented in Fig. 8 and Table 2. The data from the plumes and vertical profiles compare well for the concentrations of all aerosol and gaseous species, indicating a high level of consistency between different flights and aircraft locations.

Three altitude ranges have been used to represent the broad vertical distribution of the pollution layers. These are defined as lower, middle and upper troposphere (LT, MT, UT) and cover the altitudes $0-2500 \mathrm{~m}$ (750-1000 mbar), 2500$5500 \mathrm{~m}$ (500-75 mbar) and 5500-8000 m (350-500 mbar; Fig. 8). The height of the Arctic boundary layer (ABL) is determined to be about $200-400 \mathrm{~m}$, based on the lowest potential temperature inversion derived from the aircraft profiles. The Arctic tropopause in this study was observed to be around $7500-8000 \mathrm{~m}$ based on analysis of ozone profiles. Compared to the BG background air (Table 3), AS sources show the largest perturbation to the vertical profiles of $\mathrm{BC}$ and $\triangle \mathrm{CO}$ at levels above $2000 \mathrm{~m}$. The AS contribution to the $\mathrm{BC}$ profile was largest in the MT with a value (a)
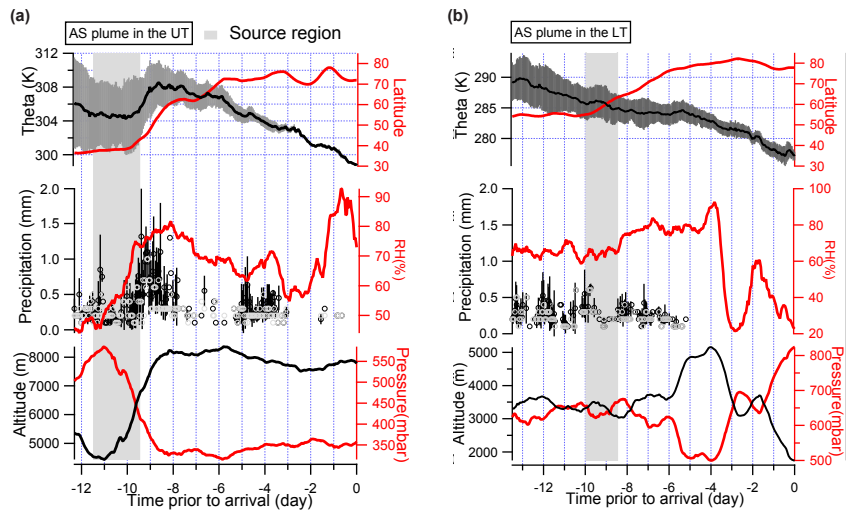

Figure 9. Average characteristics of sampled air parcel plumes arriving at receptor locations along 12-day backward trajectory pathways. Panels (a) and (b) show the cases for AS plume in the UT (corresponding to B759 $\mathrm{i}$ plume in Table 2) and LT (B760 ii in Table 2) respectively. All parameters shown are mean values averaged over all back trajectories sampled throughout the specified plume. The bars on the precipitation and potential temperature $(\theta)$ data denote the stand deviation $\pm \sigma$ of the ensemble of all back trajectories, and the grey markers on precipitation show the median value. The grey bars mark the time when the air masses passed over the source regions according to FPES. The identical plots for the other air mass regions are shown in Fig. S5.

of $100.8 \pm 48.4 \mathrm{ng} \mathrm{sm}^{-3}$; AS-derived BC plumes close to the tropopause (at $\sim 7.5-8 \mathrm{~km}$ ) were also observed with concentrations of 55 to $73 \mathrm{ng} \mathrm{sm}^{-3}$. EU air masses significantly influenced the MT, whereas air masses from the EU region made only a minor contribution to the UT. NA appears to only dominate $\Delta \mathrm{CO}$ for altitudes $<2000 \mathrm{~m}$ and $\mathrm{rBC}$ for a fraction of the LT. The sulphate concentration was $2-4$ times higher than organic matter, which is consistent with the dominance of anthropogenic sources, though there are other possible natural sources contributing the Arctic sulphate burden that may contribute (Fisher et al., 2011).

$\mathrm{BC}$ particles show relatively consistent coating thickness (within $10 \%$ ) for different air mass origins (Table 2) with average $D_{\mathrm{p}} / D_{\mathrm{c}} 2.25 \pm 0.55$, equivalent to $90-95 \%$ of the volume of $\mathrm{BC}$ containing particles being due to non-refectory material associated with the $\mathrm{BC}$-core. Although during the AS-dominated air masses, a slight vertical dependence of the BC coating thickness was observed with reduced coating thicknesses occurring at lower altitudes (Fig. S4). Compared to previous observations of lower $D_{\mathrm{p}} / D_{\mathrm{c}}$ in close proximity of sources (1.28-1.65, Liu et al., 2014; D. Liu et al., 2011), this suggests that the observed $B C$ has been significantly aged. The BC size distribution is almost uniform for AS, EU, and NA influenced air masses with mass median diameter of 190-210, 190-200, and 180-190 nm with geometric standard deviation $\sigma_{g}=1.55-1.65$. The NA showed a slightly smaller BC MMD. 
Table 3. Average statistics for $\mathrm{BC}, \Delta \mathrm{CO}, \mathrm{BC} D_{\mathrm{p}} / D_{\mathrm{c}}$, sulphate, organic mass, and $\mathrm{BC} / \Delta \mathrm{CO}$ in the lower (LT), middle (MT), and upper (UT) troposphere during periods when the different source regions dominated. For BC / $\triangle \mathrm{CO}$, both units $\mathrm{ng} \mathrm{sm}^{-3} \mathrm{ppbv}^{-1} \mathrm{and} \mathrm{mg} \mathrm{g}^{-1}$ (in branket) are presented.

\begin{tabular}{|c|c|c|c|c|}
\hline $\begin{array}{l}\text { Troposphere } \\
\text { Levels }\end{array}$ & Asia & Europe & North America & Background \\
\hline \multicolumn{5}{|c|}{$\mathrm{BC}\left(\mathrm{ng} \mathrm{sm}^{-3}\right)$} \\
\hline $\mathrm{LT}^{\mathrm{a}}$ & $32.1 \pm 26.2$ & & $21.8 \pm 14.0$ & $13.3 \pm 8.5$ \\
\hline $\mathrm{MT}^{\mathrm{b}}$ & $100.8 \pm 48.4$ & $70.8 \pm 39.1$ & $19.9 \pm 13.3$ & \\
\hline $\mathrm{UT}^{\mathrm{c}}$ & $55.8 \pm 22.4$ & $12.6 \pm 7.0$ & $23.6 \pm 16.7$ & \\
\hline \multicolumn{5}{|c|}{$\Delta \mathrm{CO}(\mathrm{ppbv})$} \\
\hline $\mathrm{LT}$ & $14.6 \pm 12.1$ & & $17.0 \pm 6.6$ & $10.4 \pm 4.3$ \\
\hline MT & $28.8 \pm 17.4$ & $24.3 \pm 12.7$ & $16.8 \pm 6.9$ & \\
\hline UT & $32.4 \pm 14.7$ & $25.3 \pm 9.9$ & $19.8 \pm 7.4$ & \\
\hline \multicolumn{5}{|c|}{$\mathrm{BC} D_{\mathrm{p}} / D_{\mathrm{c}}$} \\
\hline LT & $2.03 \pm 0.24$ & & $2.25 \pm 0.24$ & $2.21 \pm 0.29$ \\
\hline MT & $2.16 \pm 0.13$ & $2.21 \pm 0.20$ & $2.33 \pm 0.29$ & \\
\hline UT & $2.21 \pm 0.20$ & $2.28 \pm 0.40$ & $2.24 \pm 0.30$ & \\
\hline \multicolumn{5}{|c|}{ Sulphate $\left(\mathrm{ng} \mathrm{sm}^{-3}\right)$} \\
\hline $\mathrm{LT}$ & & & $870 \pm 255$ & $336 \pm 173$ \\
\hline MT & & $905 \pm 479$ & $445 \pm 213$ & \\
\hline UT & & $108 \pm 50$ & $280 \pm 121$ & \\
\hline \multicolumn{5}{|c|}{ Organic $\left(\mathrm{ng} \mathrm{sm}^{-3}\right)$} \\
\hline LT & & & $235 \pm 83$ & $94.5 \pm 73.0$ \\
\hline MT & & $210 \pm 94$ & $129 \pm 92$ & \\
\hline UT & & $97 \pm 53$ & $176 \pm 130$ & \\
\hline \multicolumn{5}{|c|}{ Measured BC / $\Delta \mathrm{CO}\left(\mathrm{ng} \mathrm{sm}^{-3} \mathrm{ppbv}^{-1}\right)\left(\mathrm{mg} \mathrm{g}^{-1}\right.$ in branket $)$} \\
\hline LT & $2.25 \pm 0.69(1.80)$ & & $1.16 \pm 0.36(0.93)$ & $1.82 \pm 0.98$ \\
\hline MT & $4.22 \pm 1.50(3.38)$ & $2.79 \pm 1.23(2.23)$ & $1.26 \pm 0.30(1.01)$ & \\
\hline UT & $2.01 \pm 1.49(1.61)$ & $1.03 \pm 0.08(0.82)$ & $1.33 \pm 0.67(1.06)$ & \\
\hline
\end{tabular}

a LT: 0-2500 m, 750-1000 hpa; ${ }^{\mathrm{b}}$ MT: 2500-5500 m, 500-750 hpa; ${ }^{\mathrm{c}}$ UT: $5500-8000 \mathrm{~m}, 350-500$ hpa.

\subsection{The transport mechanisms of air parcels}

The transport pathways of pollutants to different Arctic altitudes may vary. To investigate this, HYSPLIT back trajectories from plumes intercepted within the Arctic LT and the UT are investigated separately, as shown in Fig. 9. For each plume, physical properties including altitude, ambient pressure, latitude, precipitation, potential temperature $(\theta)$, are averaged over all back trajectories during the plume duration. The light-grey shading in Fig. 9 marks the region along the trajectory when trajectories passed over the region with the most sensitivity to the ground sources as derived from the FPES. The total precipitation experienced by an average plume (as given in Table 2) is the accumulated average precipitation along the trajectory pathway from the source emission to when the plume was observed, and the uncertainty is given by the propagation of the uncertainties of average precipitation along the trajectory pathway.

As Figs. 9 and S5 show, the sources of the UT plumes were located between $30-40^{\circ} \mathrm{N}$ whereas the sources of LT plumes were at $50-60^{\circ} \mathrm{N}$. The lower-latitude source regions have potential temperatures that are $15-20 \mathrm{~K}$ higher than those of the plumes from higher-latitude sources. The pollution plumes observed in the Arctic UT had experienced rapid vertical ascent, for example, plumes from AS and EU experienced vertical ascent of 4-5 km within 1-2 days; similar ascents rates were also observed for NA-influenced air masses but the ascent was typically over a lower altitude ( $\sim 2 \mathrm{~km}$ vertically). Ascent of sampled polluted air masses which arrived in the Arctic LT also occurred, however to a much lesser extent and on a longer timescale. Due to the close proximity of the Arctic for the higher-latitude source, the air parcel has been 
transported on a shorter timescale compared to lower-latitude sources.

Back trajectories of air masses from lower-latitude sources arriving as plumes in the UT show an increase of $\theta$ at the source during ascent of the air shortly after passing over the source region. This increase of $\theta$ is about $5 \mathrm{~K}$ for all air parcels arriving in the Arctic UT from all source regions, however there are increased uncertainties in determining $\theta$ from the model when the trajectory extends further backward in time. The increase of $\theta$ along with rapid, eastward and poleward ascent of air masses in the mid-latitudes indicates ascent to be associated with warm conveyor belts (WCBs) (Eckhardt et al., 2004), although the vertical increases in $\theta$ in our study are lower than previous work (30-40 K, Matsui et al., 2011) investigating mid-latitude air masses transported to the Arctic. In contrast to the transport of UT plume sources, the observed plumes arriving in the Arctic LT arising from high-latitude pollution sources have a lower latitudinal $\theta$ gradient and there was no obvious vertical increase of $\theta$ observed for these sources. For plumes arriving in both LT and UT, the air mass ascent was followed by a smooth decrease in potential temperature. For EU-influenced air masses, which represent the highest latitude anthropogenic sources, the change of $\theta$ was minor, suggesting the transport tends to be quasi-isentropic. The rapid ascent of lower-latitude sources was shown to be associated with heavier precipitation and increased relative humidity, compared to air parcels from higher-latitude source regions with lower precipitations.

\subsection{The scavenging of $\mathrm{BC}$ particles}

During transport, particularly during uplift, it can be expected that a significant fraction of particles are removed through scavenging and subsequent precipitation. This is an important process to quantify, as models show high sensitivity to this (e.g. Mann et al., 2014). The extent of this is estimated by comparing the particle concentrations with $\mathrm{CO}$. $\mathrm{CO}$ is not removed by precipitation and is not significantly removed by gas phase oxidation on timescales equivalent to transport from the source regions to the Arctic (within 12 days) (Forster et al., 2001). The ratio of $\mathrm{BC} / \triangle \mathrm{CO}$ can therefore be used to estimate the extent to which $\mathrm{BC}$ is removed from the air mass between the source region and the receptor (Park et al., 2005). For a specified plume, the scavenged fraction of $\mathrm{BC}\left(\mathrm{SF}_{\mathrm{BC}}\right)$ can be estimated according to Eq. (1):

$\mathrm{SF}_{\mathrm{BC}}=1-\frac{\mathrm{BC} / \Delta \mathrm{CO}_{\text {measured }}}{\mathrm{BC} / \Delta \mathrm{CO}_{\text {source }}}$

The $\mathrm{BC} / \triangle \mathrm{CO}_{\text {measured }}$ and $\mathrm{BC} / \triangle \mathrm{CO}_{\text {source }}$ represent the ratio as measured at the receptor and determined at the emission source respectively. To obtain the $\mathrm{SF}_{\mathrm{BC}}$ requires an explicit determination of the $\mathrm{BC} / \triangle \mathrm{CO}_{\text {source }}$. However, values obtained from measurements in the literature are subject to

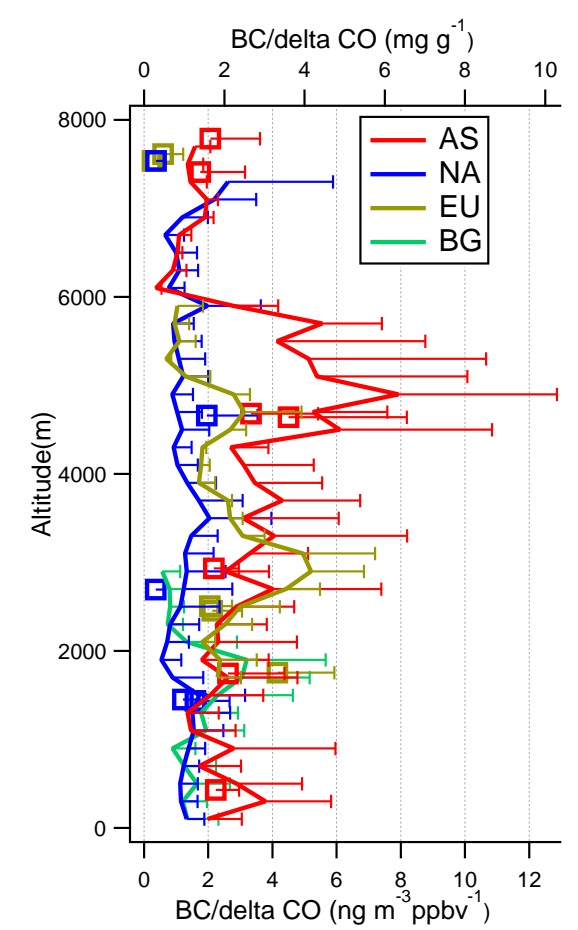

Figure 10. BC / $\triangle \mathrm{CO}$ measured during ACCACIA for different air mass origins, with the lines and square markers showing the ratio for vertical profiles and plumes respectively. The bars show the $+\sigma$.

different ageing time of samples, various source characteristics, variations in emissions throughout the year and influences on particular experimental locations, which leads to significant variations in reported $\mathrm{BC} / \triangle \mathrm{CO}$. For example a $\mathrm{BC} / \Delta \mathrm{CO}$ (in $\mathrm{ng} \mathrm{sm}^{-3} \mathrm{ppbv}^{-1}$ ) of $6.5-8.8$ was obtained in the south-east Asian boundary layer (Pan et al., 2011), in the European boundary layer $\mathrm{BC} / \triangle \mathrm{CO}$ could range from 0.8-2.3 (McMeeking et al., 2010), whereas Baumgardner et al. (2007) observed a value of 1.4 for the Mexico city urban environment. Spackman et al. (2008) report 6.8 for the Houston region and 3.8-9.4 for boreal fires in North America (Petzold et al., 2007). It is therefore more appropriate to use values of $\mathrm{BC}$ and $\mathrm{CO}$ from emission inventories as a "best estimate" to consistently evaluate the scavenging on $\mathrm{BC}$ since emission, recognizing that there is uncertainty in these values. The FPES $\times$ inventory modelled $\mathrm{BC}$ and $\triangle \mathrm{CO}$ attributed to anthropogenic and OBB sources (Table S1) are used to represent the ratio of $\mathrm{BC} / \triangle \mathrm{CO}_{\text {source}}$. The $\mathrm{SF}_{\mathrm{BC}}$ calculated by Eq. (1) can therefore be considered as the integrated scavenged fraction from emission to receptor.

The $\mathrm{BC} / \triangle \mathrm{CO}_{\text {measured }}$ for vertical profiles and plumes is shown in Fig. 10. The average $\mathrm{BC} / \triangle \mathrm{CO}_{\text {measured }}$ ranged $0.4-$ 3 for the plumes (Table 3 ) and $0.1-4.8$ for vertical profiles, and these values are of a comparable magnitude to those reported by Matsui et al. (2011). As shown in Fig. 10, AS air masses significantly increased the $\mathrm{BC} / \triangle \mathrm{CO}$ throughout the Arctic troposphere at all altitudes; NA sources also increased 
the ratio but to a considerably lesser extent; EU influenced air masses showed a $\mathrm{BC} / \triangle \mathrm{CO}$ measured that was enhanced by a similar order of magnitude as that in the AS-influenced air masses in the mid troposphere, but a lack of available data for LT prevented a similar comparison being made for EU. The plumes in the UT experienced heavier precipitation for both AS- and EU-influenced plumes (Table 2).

The $\mathrm{SF}_{\mathrm{BC}}$ was calculated for each intercepted plume and ranges from 0.6-0.95 (Table S2). The dependence of $\mathrm{SF}_{\mathrm{BC}}$ for each plume on precipitation integrated along the trajectory is shown in Fig. 11. In contrast to the previous observation by Matsui et al. (2011), where the BC removal was observed to be significantly correlated to the precipitation intensity, in this study no obvious correlation between precipitation and $\mathrm{SF}_{\mathrm{BC}}$ was observed. This may be due to the uncertainties of modelled precipitation along the back trajectories, or the scavenging of $\mathrm{BC}$ via precipitation was subject to a complex mechanism not well represented by the total precipitation. The main contrast between this study and Matsui et al. (2011) is the significantly higher $\mathrm{BC} / \triangle \mathrm{CO}$ for air masses influenced by Asia; $\mathrm{BC} / \Delta \mathrm{CO}$ was most elevated (3-8) in the mid troposphere at altitudes of 4-6 km, influenced mainly by mid-latitude Asian sources, indicating that the lowest scavenging efficiencies were observed in these regions.

\section{Discussion}

In this study, Asian sources were observed to influence all levels of the troposphere $(400-8000 \mathrm{~m})$ : the source origins include higher-latitude northern China $\left(\sim 40-60^{\circ} \mathrm{N}\right)$ and a mid-latitude $\left(\sim 30-40^{\circ} \mathrm{N}\right)$ region including eastern China and Japan. The influences on the Arctic MT/UT were mainly from the mid-latitude sources, for which the air parcel could be rapidly uplifted by WCBs to the free troposphere and then followed by a long-range northeastward transport to the Arctic MT/UT. These observations are consistent with previous studies that indicate long-range transported fossil fuel sources from Northern Hemisphere mid-latitude affect the Arctic MT/UT (Stohl, 2006; Quinn et al., 2007, and references therein).

Air masses influenced by northern European sources may follow various pathways to reach the Arctic (Stohl, 2006). Transport of these air masses to high altitudes within the Arctic atmosphere has previously been shown to arise via WCBs (Marelle et al., 2015), however this was only clearly the case for southern European influenced air masses. In several cases both uplift through WCBs and quasi-isentropic transport may operate in combination during transport to the Arctic region. However, consistent with previous studies (Stohl, 2006; Marelle et al., 2014), we show that the influence of European sources on the Arctic UT is low.

Air masses influenced by North American sources were generally observed to be lifted to a lower altitude, followed by a longer transport time. The influence of NA sources in

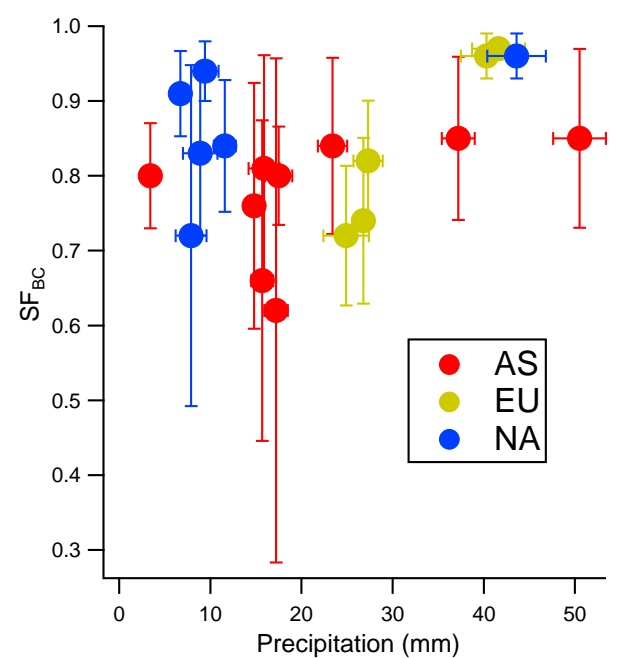

Figure 11. The calculated scavenged fraction of $\mathrm{BC}\left(\mathrm{SF}_{\mathrm{BC}}\right)$ vs. accumulated precipitation, with the bars showing the \pm propagated uncertainties for both precipitation and $\mathrm{SF}_{\mathrm{BC}}$.

the Arctic free troposphere in the vicinity of Greenland were previously reported (Quennehen et al., 2011), however most of the previous studies have reported weak or occasional influence of NA sources on the Arctic (e.g. Stohl, 2006; McConnell et al., 2007; Brock et al., 2011), which is to be expected as the main industrial sources in NA lie southward of the mean position of the Arctic front, and since advection from these sources to the Arctic involves transport through the meteorologically active North Atlantic region. This study is consistent with those previous results in that the observed NA influences were close to, or only slightly higher than the background conditions.

The main contrast between this study and those conducted previously is that high-latitude OBB sources from Eastern Europe and Siberia did not make a significant contribution to $\mathrm{BC}$ in the Arctic atmosphere; whereas in springtime of 2008, OBB sources were prevalent in these regions (e.g. Brock et al., 2011; Warneke et al., 2009). As a result, our results show that during spring 2013, the OBB contribution to the Arctic $\mathrm{BC}$ burden was less than $10 \%$, a result that is consistent with the high relative sulphate concentrations observed in all sampled plumes. This contrasts with the springtime of 2008 when the aerosols in observed Arctic plumes had a higher organic content than sulphate (e.g. Brock et al., 2011; Warneke et al., 2009; Jacob et al., 2010). Annual fire counts across Siberia from the FINN emissions inventory for March-April over the 10-year period from 2004 to 2013 are shown in Fig. 12a. The year 2008 is shown to be anomalously high, compared to the decadal average of $2.8 \times 10^{4}$ by approximately a factor of 2.4. In all other years in the last decade fire counts in the Siberia spring varied between $1.4 \times 10^{4}$ and $3.7 \times 10^{4}$. This contrasts with 2013 which showed the lowest number of fire counts $\left(1.4 \times 10^{4}\right)$. Therefore, whilst 2008 does indeed show 

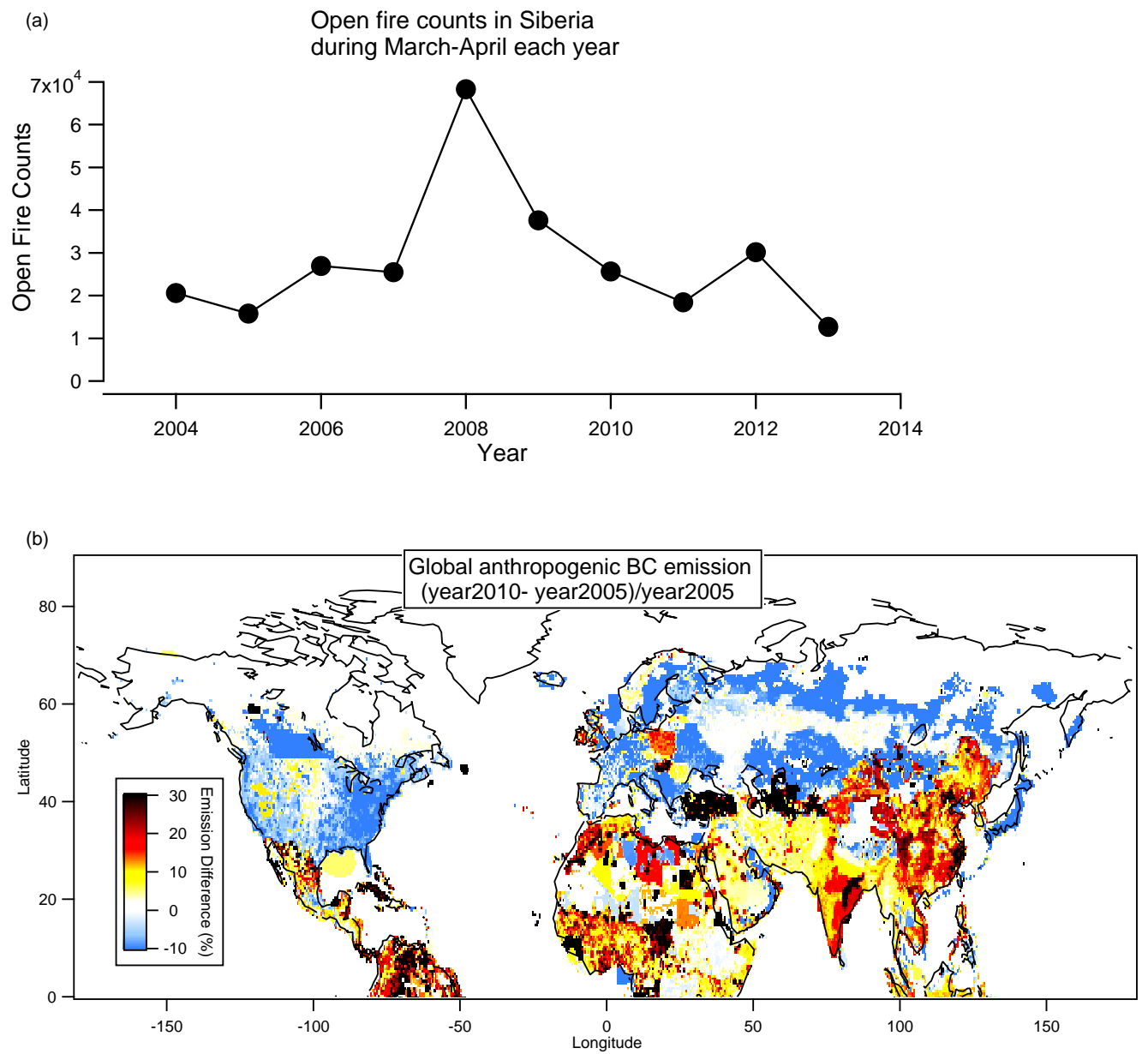

Figure 12. (a) Fire counts from FINN in Siberia region $\left(50-70^{\circ} \mathrm{N}, 30-180^{\circ}\right.$ E) during March and April from 2004 to 2013 . (b) Percentage difference between total anthropogenic BC emissions from the ECLIPSE global BC inventory in 2010 and 2005.

the importance of biomass burning in the Arctic, Asian pollution sources make a substantial contribution to Arctic BC during many spring seasons. Figure $12 \mathrm{~b}$ shows the changes in anthropogenic emissions of BC between 2005 and 2010 as described in the ECLIPSE database. There is a marked increase in BC emissions over this period of between 20-30\% and these increases are projected to continue in the coming decades.

A number of studies point out the scavenging efficiency of $\mathrm{BC}$ represents a major uncertainty in model prediction of $\mathrm{BC}$ in the Arctic (e.g. J. Liu et al., 2011; Hodnebrog et al., 2014; Myhre and Samset, 2015), and these studies have shown that models could underestimate the BC loadings in the Arctic during the cold season by a factor of up to 10 due to a possible underestimation of the BC lifetime. Improved agreement between model and measurement is achieved for many of the models by reducing the scavenging efficiency in ice cloud during the winter and spring time in the Arctic. The hygroscopicity of BC can be increased by acquiring more hygroscopic materials (Liu et al., 2013), such as sulphate, a process that is sometimes parameterized in models by changing its solubility after sometime in the atmosphere. This process may be only efficiently applied to warm clouds. For ice clouds, the water soluble coatings on BC may inhibit its ice nucleation activity (Koehler et al., 2009). The aerosols however may also experience removal by processes other than ice nucleation, for example through impaction onto ice surfaces (Baumgardner et al., 2008), scavenging by convective clouds (Koch, 2011), or wash out by below cloud precipitation. The integrated $\mathrm{SF}_{\mathrm{BC}}$ of $0.60-0.95$ from this study provides a constraint for future model tests.

\section{Conclusions}

Intercontinental transport of pollutants to the European Arctic was observed during the ACCACIA campaign in springtime 2013. FLEXPART-WRF Lagrangian dispersion modelling was performed to evaluate contributions of ground sources to the sampled air masses. When this analysis was combined with up-to-date emission inventories, anthro- 
pogenic sources in populous regions were found to contribute over $90 \%$ of the BC for all the plumes sampled. In contrast to previous observations, open wildfire contributions from Siberia and Eastern Europe to the observed enhanced BC were small. Our measurements of significantly higher sulphate content compared to organic matter are consistent with this. Within the plumes observed, Asian sources were found to have the most significant influence at all levels throughout the Arctic troposphere, with the maximum BC mass loading arising in the middle troposphere (MT) at concentrations of around $100 \mathrm{ng} \mathrm{sm}^{-3}$. European sources (EU) also have an important influence in the MT and are an order of magnitude lower than those from Asia. Due to the high-latitude location of the sources, Europe does not significantly influence the Arctic upper troposphere (UT). North American sources (NA) displayed a weak influence at all altitudes largely due to the longer transport time and active meteorological influences.

The transport from Asian pollution sources is likely to be facilitated by warm conveyor belts, through which air parcels are rapidly uplifted on timescales of 1-2 days, followed by long-range transport (8.5-11.5 days). We show that this pathway efficiently transports BC from mid-latitude Asian sources to the high-altitude Artic troposphere, raising $\mathrm{BC}$ concentrations to between 55 and $73 \mathrm{ng} \mathrm{sm}^{-3}$ close to the Arctic tropopause. The scavenged fraction of $\mathrm{BC}$ for plumes was estimated by comparing the measured $\mathrm{BC}$ abundance relative to the measured excess $\mathrm{CO}$ with the same ratio derived from values at source determined from the EDGAR and FINN emission inventories. This showed that about 60 $95 \%$ of $\mathrm{BC}$ is scavenged between the source region and the Arctic atmosphere where the measurements took place. No direct correlation was found between the scavenged fraction and accumulated precipitation.

Compared to previous studies when plumes from open fire sources were intensively observed, this study shows that open fire contributions to BC vary significantly between years and are sporadic, whereas the contribution of Asian sources to pollution in the Arctic atmosphere is substantial and is delivered via a persistent and consistent pathway. Asian outflow will accumulate in the Artic troposphere during the winter season and early spring, being retained north of the polar front in slowly descending cold polar air. The radiation balance of the upper tropospheric Arctic atmosphere has been shown to be very sensitive to absorbing aerosol in spring time and given that Asian pollution is likely to continue to rise over the coming years it is likely that this process will continue to increase in importance when considering regional climate effects.

\section{Data availability}

Processed data are available through the ACCACIA project archive at the British Atmospheric Data Centre (http://badc. nerc.ac.uk/browse/badc/accacia). Raw data are archived at the University of Manchester and is available on request.

\section{The Supplement related to this article is available online at doi:10.5194/acp-15-11537-2015-supplement.}

Acknowledgements. This work was supported by the Natural Environment Research Council (NERC) through the ACCACIA (NE/I028696/1) and GASSP (NE/J023515/1) projects. The BAe146-301 Atmospheric Research Aircraft was flown by Directflight Ltd and managed by the Facility for Airborne Atmospheric Measurements (FAAM), a joint entity of NERC and the Met Office. Boris Quennehen acknowledges the European Union for funding the FP7 ECLIPSE project (grant agreement no. 282688) as well as the IPSL CICLAD/CLIMSERV mesocenter for providing computing resources.

Edited by: L. M. Russell

\section{References}

Baumgardner, D., Kok, G. L., and Raga, G. B.: On the diurnal variability of particle properties related to light absorbing carbon in Mexico City, Atmos. Chem. Phys., 7, 2517-2526, doi:10.5194/acp-7-2517-2007, 2007.

Baumgardner, D., Subramanian, R., Twohy, C., Stith, J., and Kok, G.: Scavenging of black carbon by ice crystals over the northern Pacific, Geophys. Res. Lett., 35, L22815, doi:10.1029/2008GL035764, 2008.

Baumgardner, D., Popovicheva, O., Allan, J., Bernardoni, V., Cao, J., Cavalli, F., Cozic, J., Diapouli, E., Eleftheriadis, K., Genberg, P. J., Gonzalez, C., Gysel, M., John, A., Kirchstetter, T. W., Kuhlbusch, T. A. J., Laborde, M., Lack, D., Müller, T., Niessner, R., Petzold, A., Piazzalunga, A., Putaud, J. P., Schwarz, J., Sheridan, P., Subramanian, R., Swietlicki, E., Valli, G., Vecchi, R., and Viana, M.: Soot reference materials for instrument calibration and intercomparisons: a workshop summary with recommendations, Atmos. Meas. Tech., 5, 1869-1887, doi:10.5194/amt-51869-2012, 2012.

Bond, T. C., Doherty, S. J., Fahey, D. W., Forster, P. M., Berntsen, T., DeAngelo, B. J., Flanner, M. G., Ghan, S., Kärcher, B., Koch, D., Kinne, S., Kondo, Y., Quinn, P. K., Sarofim, M C., Schultz, M. G., Schulz, M., Venkataraman, C., Zhang, H., Zhang, S., Bellouin, N., Guttikunda, S. K., Hopke, P. K., Jacobson, M. Z., Kaiser, J. W., Klimont, Z., Lohmann, U., Schwarz, J. P., Shindell, D., Storelvmo, T., Warren, S. G., and Zender, C. S.: Bounding the role of black carbon in the climate system: A scientific assessment, J. Geophys. Res., 118, 5380-5552, doi:10.1002/jgrd.50171, 2013.

Bourgeois, Q. and Bey, I.: Pollution transport efficiency toward the Arctic: Sensitivity to aerosol scavenging and source regions, J. Geophys. Res., 116, D08213, doi:10.1029/2010JD015096, 2011.

Brioude, J., Arnold, D., Stohl, A., Cassiani, M., Morton, D., Seibert, P., Angevine, W., Evan, S., Dingwell, A., Fast, J. D., 
Easter, R. C., Pisso, I., Burkhart, J., and Wotawa, G.: The Lagrangian particle dispersion model FLEXPART-WRF version 3.1, Geosci. Model Dev., 6, 1889-1904, doi:10.5194/gmd-61889-2013, 2013.

Brock, C. A., Cozic, J., Bahreini, R., Froyd, K. D., Middlebrook, A. M., McComiskey, A., Brioude, J., Cooper, O. R., Stohl, A., Aikin, K. C., de Gouw, J. A., Fahey, D. W., Ferrare, R. A., Gao, R.-S., Gore, W., Holloway, J. S., Hübler, G., Jefferson, A., Lack, D. A., Lance, S., Moore, R. H., Murphy, D. M., Nenes, A., Novelli, P. C., Nowak, J. B., Ogren, J. A., Peischl, J., Pierce, R. B., Pilewskie, P., Quinn, P. K., Ryerson, T. B., Schmidt, K. S., Schwarz, J. P., Sodemann, H., Spackman, J. R., Stark, H., Thomson, D. S., Thornberry, T., Veres, P., Watts, L. A., Warneke, C., and Wollny, A. G.: Characteristics, sources, and transport of aerosols measured in spring 2008 during the aerosol, radiation, and cloud processes affecting Arctic Climate (ARCPAC) Project, Atmos. Chem. Phys., 11, 2423-2453, doi:10.5194/acp-11-24232011, 2011.

Browse, J., Carslaw, K. S., Arnold, S. R., Pringle, K., and Boucher, O.: The scavenging processes controlling the seasonal cycle in Arctic sulphate and black carbon aerosol, Atmos. Chem. Phys., 12, 6775-6798, doi:10.5194/acp-12-6775-2012, 2012.

Draxler, R. R. and Hess, G. D.: An Overview of the HYSPLIT_4 Modelling System for Trajectories, Dispersion, and Deposition, Aust. Meteorol. Mag., 47, 295-308, 1998.

Drewnick, F., Hings, S. S., Decarlo, P. F., Jayne, J. T., Gonin, M., Fuhrer, K., Weimer, S., Jimenez, J. L., Demerjian, K. L., Borrmann, S., and Worsnop, D. R.: A new time-of-flight aerosol mass spectrometer (TOF-AMS) - Instrument description and first field deployment, Aerosol Sci. Tech., 39, 637-658, doi:10.1080/02786820500182040, 2005.

Eckhardt, S., Stohl, A., Wernli, H., James, P., Forster, C., and Spichtinger, N.: A 15-year climatology of warm conveyor belts, J. Climate, 17, 218-237, 2004.

Fisher, J. A., Jacob, D. J., Wang, Q., Bahreini, R., Carouge, C. C., Cubison, M. J., Dibb, J. E., Diehl, T., Jimenez, J. L., Leibensperger, E. M., Lu, Z., Meinders, M. B. J., Pye, H. O. T., Quinn, P. K., Sharma, S., Streets, D. G., van Donkelaar, A., and Yantosca, R. M.: Sources, distribution, and acidity of sulfateammonium aerosol in the Arctic in winter-spring, Atmos. Environ., 45, 7301-7318, doi:10.1016/j.atmosenv.2011.08.030, 2011.

Flanner, M. G., Zender, C. S., Randerson, J. T., and Rasch, P. J.: Present-day climate forcing and response from black carbon in snow, J. Geophys. Res.-Atmos., 112, D11202, doi:10.1029/2006JD008003, 2007.

Forster, C., Wandinger, U., Wotawa, G., James, P., Mattis, I., Althausen, D., Simmonds, P., O'Doherty, S., Jennings, S. G., Kleefeld, C., Schneider, J., Trickl, T., Kreipl, S., Jäger, H., and Stohl, A.: Transport of boreal forest fire emissions from Canada to Europe, J. Geophys. Res., 106, 22887-22906, doi:10.1029/2001JD900115, 2001.

Frossard, A. A., Shaw, P., Russell, L. M., Kroll, J. H., Canagaratna, M. J., Worsnop, D. R., Quinn, P. K., and Bates, T. S.: Springtime Arctic haze contributions of submicron organic particles from European and Asian combustion sources, J. Geophys. Res., 116, D05205, doi:10.1029/2010JD015178, 2011.

Garrett, T. J. and Zhao, C.: Increased Arctic cloud longwave emissivity associated with pollution from mid-latitudes, Nature, 440, 787-789, doi:10.1038/nature04636, 2006.
Greenaway, K. R.: Experiences with Arctic flying weather, Royal Meteorol. Soc. Can. Branch, Toronto, Ontario, Canada, 1950.

Hansen, J. and Nazarenko, L.: Soot climate forcing via snow and ice albedos, P. Natl. Acad. Sci. USA, 101, 423-428, doi:10.1073/pnas.2237157100, 2004.

Hodnebrog, Ø., Myhre, G., and Samset, B. H.: How shorter black carbon lifetime alters its climate effect, Nat. Commun., 5, 5065, doi:10.1038/ncomms6065, 2014.

IPCC Working Group 2: Impacts, Adaptation and Vulnerability, available at: http://www.ipcc.ch/report/ar5/wg2 (last access: May 2015), 2014.

Jacob, D. J., Crawford, J. H., Maring, H., Clarke, A. D., Dibb, J. E., Emmons, L. K., Ferrare, R. A., Hostetler, C. A., Russell, P. B., Singh, H. B., Thompson, A. M., Shaw, G. E., McCauley, E., Pederson, J. R., and Fisher, J. A.: The Arctic Research of the Composition of the Troposphere from Aircraft and Satellites (ARCTAS) mission: design, execution, and first results, Atmos. Chem. Phys., 10, 5191-5212, doi:10.5194/acp-10-5191-2010, 2010.

Klonecki, A., Hess, P., Emmons, L., Smith, L., Orlando, J., and Blake, D.: Seasonal changes in the transport of pollutants into the Arctic troposphere - Model study, J. Geophys. Res., 108, 8367, doi:10.1029/2002JD002199, 2003.

Koch, D.: The transport and direct radiative forcing of carbonaceous and sulfate aerosols in the GISS GCM, J. Geophys. Res., 106, 20311-20332, 2001.

Koch, D. and Hansen, J.: Distant origins of Arctic black carbon: A Goddard Institute for Space Studies ModelE experiment, J. Geophys. Res., 110, D04204, doi:10.1029/2004JD005296, 2005.

Koch, D., Schulz, M., Kinne, S., McNaughton, C., Spackman, J. R., Balkanski, Y., Bauer, S., Berntsen, T., Bond, T. C., Boucher, O., Chin, M., Clarke, A., De Luca, N., Dentener, F., Diehl, T., Dubovik, O., Easter, R., Fahey, D. W., Feichter, J., Fillmore, D., Freitag, S., Ghan, S., Ginoux, P., Gong, S., Horowitz, L., Iversen, T., Kirkevåg, A., Klimont, Z., Kondo, Y., Krol, M., Liu, X., Miller, R., Montanaro, V., Moteki, N., Myhre, G., Penner, J. E., Perlwitz, J., Pitari, G., Reddy, S., Sahu, L., Sakamoto, H., Schuster, G., Schwarz, J. P., Seland, Ø., Stier, P., Takegawa, N., Takemura, T., Textor, C., van Aardenne, J. A., and Zhao, Y.: Evaluation of black carbon estimations in global aerosol models, Atmos. Chem. Phys., 9, 9001-9026, doi:10.5194/acp-9-9001-2009, 2009.

Koehler, K. A., DeMott, P. J., Kreidenweis, S. M., Popovicheva, O. B., Petters, M. D., Carrico, C. M., Kireeva, E. D., Khokhlova, T. D., and Shonija, N. K.: Cloud condensation nuclei and ice nucleation activity of hydrophobic and hydrophilic soot particles., Phys. Chem. Chem. Phys., 11, 7906-7920, doi:10.1039/b905334b, 2009.

Koike, M., Kondo, Y., Kita, K., Takegawa, N., Masui, Y., Miyazaki, Y., Ko, M., Weinheimer, A., Flocke, F., and Weber, R.: Export of anthropogenic reactive nitrogen and sulfur compounds from the east Asia region in spring. J. Geophys. Res., 108, 8789, doi:10.1029/2002JD003284, 2003.

Law, K. S. and Stohl, A.: Arctic air pollution: Origins and impacts, Science, 315, 1537-1540, doi:10.1126/science.1137695, 2007.

Lee, Y. H., Lamarque, J.-F., Flanner, M. G., Jiao, C., Shindell, D. T., Berntsen, T., Bisiaux, M. M., Cao, J., Collins, W. J., Curran, M., Edwards, R., Faluvegi, G., Ghan, S., Horowitz, L. W., McConnell, J. R., Ming, J., Myhre, G., Nagashima, T., Naik, V., Rumbold, S. T., Skeie, R. B., Sudo, K., Takemura, T., Thevenon, 
F., Xu, B., and Yoon, J.-H.: Evaluation of preindustrial to presentday black carbon and its albedo forcing from Atmospheric Chemistry and Climate Model Intercomparison Project (ACCMIP), Atmos. Chem. Phys., 13, 2607-2634, doi:10.5194/acp13-2607-2013, 2013.

Liu, D., Flynn, M., Gysel, M., Targino, A., Crawford, I., Bower, K., Choularton, T., Jurányi, Z., Steinbacher, M., Hüglin, C., Curtius, J., Kampus, M., Petzold, A., Weingartner, E., Baltensperger, U., and Coe, H.: Single particle characterization of black carbon aerosols at a tropospheric alpine site in Switzerland, Atmos. Chem. Phys., 10, 7389-7407, doi:10.5194/acp-10-73892010, 2010.

Liu, D., Allan, J., Corris, B., Flynn, M., Andrews, E., Ogren, J., Beswick, K., Bower, K., Burgess, R., Choularton, T., Dorsey, J., Morgan, W., Williams, P. I., and Coe, H.: Carbonaceous aerosols contributed by traffic and solid fuel burning at a polluted rural site in Northwestern England, Atmos. Chem. Phys., 11, 1603-1619, doi:10.5194/acp-11-1603-2011, 2011

Liu, D., Allan, J., Whitehead, J., Young, D., Flynn, M., Coe, H., McFiggans, G., Fleming, Z. L., and Bandy, B.: Ambient black carbon particle hygroscopic properties controlled by mixing state and composition, Atmos. Chem. Phys., 13, 2015-2029, doi:10.5194/acp-13-2015-2013, 2013.

Liu, D., Allan, J. D., Young, D. E., Coe, H., Beddows, D., Fleming, Z. L., Flynn, M. J., Gallagher, M. W., Harrison, R. M., Lee, J., Prevot, A. S. H., Taylor, J. W., Yin, J., Williams, P. I., and Zotter, P.: Size distribution, mixing state and source apportionment of black carbon aerosol in London during wintertime, Atmos. Chem. Phys., 14, 10061-10084, doi:10.5194/acp14-10061-2014, 2014.

Liu, D., Taylor, J. W., Young, D. E., Flynn, M. J., Coe, H., and Allan, J. D.: The effect of complex black carbon microphysics on the determination of the optical properties of brown carbon, Geophys. Res. Lett., 42, 613-619, doi:10.1002/2014GL062443, 2015.

Liu, J., Fan, S., Horowitz, L. W., and Levy II, H.: Evaluation of factors controlling long-range transport of black carbon to the Arctic, J. Geophys. Res., 116, D00A14, doi:10.1029/2010JD015145, 2011.

López-Yglesias, X. and Flagan, R. C.: Ion-Aerosol Flux Coefficients and the Steady-State Charge Distribution of Aerosols in a Bipolar Ion Environment, Aerosol Sci. Technol., 47, 688-704, doi:10.1080/02786826.2013.783684, 2013.

Lund, M. T. and Berntsen, T.: Parameterization of black carbon aging in the OsloCTM2 and implications for regional transport to the Arctic, Atmos. Chem. Phys., 12, 6999-7014, doi:10.5194/acp-12-6999-2012, 2012.

Mann, G. W., Carslaw, K. S., Reddington, C. L., Pringle, K. J., Schulz, M., Asmi, A., Spracklen, D. V., Ridley, D. A., Woodhouse, M. T., Lee, L. A., Zhang, K., Ghan, S. J., Easter, R. C., Liu, X., Stier, P., Lee, Y. H., Adams, P. J., Tost, H., Lelieveld, J., Bauer, S. E., Tsigaridis, K., van Noije, T. P. C., Strunk, A., Vignati, E., Bellouin, N., Dalvi, M., Johnson, C. E., Bergman, T., Kokkola, H., von Salzen, K., Yu, F., Luo, G., Petzold, A., Heintzenberg, J., Clarke, A., Ogren, J. A., Gras, J., Baltensperger, U., Kaminski, U., Jennings, S. G., O’Dowd, C. D., Harrison, R. M., Beddows, D. C. S., Kulmala, M., Viisanen, Y., Ulevicius, V., Mihalopoulos, N., Zdimal, V., Fiebig, M., Hansson, H.-C., Swietlicki, E., and Henzing, J. S.: Intercomparison and evaluation of global aerosol microphysical properties among AeroCom models of a range of complexity, Atmos. Chem. Phys., 14, 4679-4713, doi:10.5194/acp-14-4679-2014, 2014.

Marelle, L., Raut, J.-C., Thomas, J. L., Law, K. S., Quennehen, B., Ancellet, G., Pelon, J., Schwarzenboeck, A., and Fast, J. D.: Transport of anthropogenic and biomass burning aerosols from Europe to the Arctic during spring 2008, Atmos. Chem. Phys., 15, 3831-3850, doi:10.5194/acp-15-3831-2015, 2015.

Matsui, H., Kondo, Y., Moteki, N., Takegawa, N., Sahu, L. K., Zhao, Y., Fuelberg, H. E., Sessions, W. R., Diskin, G., Blake, D. R., Wisthaler, A., and Koike, M.: Seasonal variation of the transport of black carbon aerosol from the Asian continent to the Arctic during the ARCTAS aircraft campaign, J. Geophys. Res.-Atmos., 116, D05202, doi:10.1029/2010JD015067, 2011.

McConnell, J. R., Edwards, R., Kok, G. L., Flanner, M. G., Zender, C. S., Saltzman, E. S., Banta, J. R., Pasteris, D. R., Carter, M. M., and Kahl, J. D. W.: 20th-century industrial black carbon emissions altered Arctic climate forcing, Science, 317, 1381-1384, doi:10.1126/science.1144856, 2007.

McMeeking, G. R., Hamburger, T., Liu, D., Flynn, M., Morgan, W. T., Northway, M., Highwood, E. J., Krejci, R., Allan, J. D., Minikin, A., and Coe, H.: Black carbon measurements in the boundary layer over western and northern Europe, Atmos. Chem. Phys., 10, 9393-9414, doi:10.5194/acp-10-9393-2010, 2010.

Middlebrook, A. M., Bahreini, R., Jimenez, J. L., and Canagaratna, M. R.: Evaluation of Composition-Dependent Collection Efficiencies for the Aerodyne Aerosol Mass Spectrometer using Field Data, Aerosol Sci. Tech., 46, 258-271, doi:10.1080/02786826.2011.620041, 2012.

Myhre, G. and Samset, B. H.: Standard climate models radiation codes underestimate black carbon radiative forcing, Atmos. Chem. Phys., 15, 2883-2888, doi:10.5194/acp-15-2883-2015, 2015.

Pan, X. L., Kanaya, Y., Wang, Z. F., Liu, Y., Pochanart, P., Akimoto, H., Sun, Y. L., Dong, H. B., Li, J., Irie, H., and Takigawa, M.: Correlation of black carbon aerosol and carbon monoxide in the high-altitude environment of Mt. Huang in Eastern China, Atmos. Chem. Phys., 11, 9735-9747, doi:10.5194/acp-11-97352011, 2011.

Park, R. J., Jacob, D. J., Palmer, P. I., Clarke, A. D., Weber, R. J., Zondlo, M. A., Eisele, F. L., Bandy, A. R., Thornton, D. C., Sachse, G. W., and Bond, T. C.: Export efficiency of black carbon aerosol in continental outflow: Global implications, J. Geophys. Res., 110, D11205, doi:10.1029/2004jd005432, 2005.

Petzold, A., Weinzierl, B., Huntrieser, H., Stohl, A., Real, E., Cozic, J., Fiebig, M., Hendricks, J., Lauer, A., Law, K., Roiger, A., Schlager, H., and Weingartner, E.: Perturbation of the European free troposphere aerosol by North American forest fire plumes during the ICARTT-ITOP experiment in summer 2004, Atmos. Chem. Phys., 7, 5105-5127, doi:10.5194/acp-7-51052007, 2007.

Petzold, A., Ogren, J. A., Fiebig, M., Laj, P., Li, S.-M., Baltensperger, U., Holzer-Popp, T., Kinne, S., Pappalardo, G., Sugimoto, N., Wehrli, C., Wiedensohler, A., and Zhang, X.-Y.: Recommendations for reporting "black carbon" measurements, Atmos. Chem. Phys., 13, 8365-8379, doi:10.5194/acp-13-83652013, 2013.

Polissar, A., Hopke, P., Paatero, P., Kaufmann, Y., Hall, D., Bodhaine, B., Dutton, E., and Harris, J.: The aerosol at Barrow, 
Alaska: Long-term trends and source locations, Atmos. Environ., 33, 2441-2458, 1999.

Pueschel, R. and Kinne, S.: Physical and radiative properties of Arctic atmospheric aerosols, Sci. Tot. Environ., 160-161, 811-824, doi:10.1016/0048-9697(95)04414-V, 1995.

Quennehen, B., Schwarzenboeck, A., Schmale, J., Schneider, J., Sodemann, H., Stohl, A., Ancellet, G., Crumeyrolle, S., and Law, K. S.: Physical and chemical properties of pollution aerosol particles transported from North America to Greenland as measured during the POLARCAT summer campaign, Atmos. Chem. Phys., 11, 10947-10963, doi:10.5194/acp-11-10947-2011, 2011.

Quennehen, B., Schwarzenboeck, A., Matsuki, A., Burkhart, J. F., Stohl, A., Ancellet, G., and Law, K. S.: Anthropogenic and forest fire pollution aerosol transported to the Arctic: observations from the POLARCAT-France spring campaign, Atmos. Chem. Phys., 12, 6437-6454, doi:10.5194/acp-12-6437-2012, 2012.

Quinn, P. K., Miller, T. L., Bates, T. S., Ogren, J. A., Andrews, E., and Shaw, G. E.: A three-year record of simultaneously measured aerosol chemical and optical properties at Barrow, Alaska, J. Geophys. Res., 107, AAC 8-1-AAC 8-15, doi:10.1029/2001JD001248, 2002.

Quinn, P. K., Shaw, G., Andrews, E., Dutton, E. G., Ruoho-Airola, T., and Gong, S. L.: Arctic haze: current trends and knowledge gaps, Tellus B, 59, 99-114, 2007.

Raatikainen, T., Brus, D., Hyvärinen, A.-P., Svensson, J., Asmi, E., and Lihavainen, H.: Black carbon concentrations and mixing state in the Finnish Arctic, Atmos. Chem. Phys., 15, 1005710070, doi:10.5194/acp-15-10057-2015, 2015.

Reid, J. S., Koppmann, R., Eck, T. F., and Eleuterio, D. P.: A review of biomass burning emissions part II: intensive physical properties of biomass burning particles, Atmos. Chem. Phys., 5, 799825, doi:10.5194/acp-5-799-2005, 2005.

Sakamoto, K. M., Allan, J. D., Coe, H., Taylor, J. W., Duck, T. J., and Pierce, J. R.: Aged boreal biomass-burning aerosol size distributions from BORTAS 2011, Atmos. Chem. Phys., 15, 16331646, doi:10.5194/acp-15-1633-2015, 2015.

Sharma, S., Lavoue, D., Cachier, H., Barrie, L., and Gong, S.: Long-term trends of the black carbon concentrations in the Canadian Arctic, J. Geophys. Res., 109, D15203, doi:10.1029/2003JD004331, 2004.

Sharma, S., Andrews, E., Barrie, L. A., Ogren, J. A., and Lavoue, D.: Variations and sources of the equivalent black carbon in the high Arctic revealed by long-term observations at Alert and Barrow: 1989-2003, J. Geophys. Res., 111, D14208, doi:10.1029/2005JD006581, 2006.

Shaw, P. M., Russell, L. M., Jefferson, A., and Quinn, P. K.: Arctic organic aerosol measurements show particles from mixed combustion in spring haze and from frost flowers in winter, Geophys. Res. Lett., 37, L10803, doi:10.1029/2010GL042831, 2010.

Shindell, D. T., Chin, M., Dentener, F., Doherty, R. M., Faluvegi, G., Fiore, A. M., Hess, P., Koch, D. M., MacKenzie, I. A., Sanderson, M. G., Schultz, M. G., Schulz, M., Stevenson, D. S., Teich, H., Textor, C., Wild, O., Bergmann, D. J., Bey, I., Bian, H., Cuvelier, C., Duncan, B. N., Folberth, G., Horowitz, L. W., Jonson, J., Kaminski, J. W., Marmer, E., Park, R., Pringle, K. J., Schroeder, S., Szopa, S., Takemura, T., Zeng, G., Keating, T. J., and Zuber, A.: A multi-model assessment of pollution transport to the Arctic, Atmos. Chem. Phys., 8, 5353-5372, doi:10.5194/acp-85353-2008, 2008.
Spackman, J. R., Schwarz, J. P., Gao, R. S., Watts, L. A., Thomson, D. S., Fahey, D. W., Holloway, J. S., de Gouw, J. A., Trainer, M., and Ryerson, T. B.: Empirical correlations between black carbon aerosol and carbon monoxide in the lower and middle troposphere, Geophys. Res. Lett., 35, L19816, doi:10.1029/2008GL035237, 2008.

Stohl, A.: Characteristics of atmospheric transport into the Arctic troposphere, J. Geophys. Res., 111, D11306, doi:10.1029/2005JD006888, 2006.

Stohl, A., Forster, C., Frank, A., Seibert, P., and Wotawa, G.: Technical note: The Lagrangian particle dispersion model FLEXPART version 6.2, Atmos. Chem. Phys., 5, 2461-2474, doi:10.5194/acp-5-2461-2005, 2005.

Stohl, A., Berg, T., Burkhart, J. F., Fjǽraa, A. M., Forster, C., Herber, A., Hov, Ø., Lunder, C., McMillan, W. W., Oltmans, S., Shiobara, M., Simpson, D., Solberg, S., Stebel, K., Ström, J., Tørseth, K., Treffeisen, R., Virkkunen, K., and Yttri, K. E.: Arctic smoke - record high air pollution levels in the European Arctic due to agricultural fires in Eastern Europe in spring 2006, Atmos. Chem. Phys., 7, 511-534, doi:10.5194/acp-7-511-2007, 2007.

Stohl, A., Klimont, Z., Eckhardt, S., Kupiainen, K., Shevchenko, V. P., Kopeikin, V. M., and Novigatsky, A. N.: Black carbon in the Arctic: the underestimated role of gas flaring and residential combustion emissions, Atmos. Chem. Phys., 13, 8833-8855, doi:10.5194/acp-13-8833-2013, 2013.

Stohl, A., Aamaas, B., Amann, M., Baker, L. H., Bellouin, N., Berntsen, T. K., Boucher, O., Cherian, R., Collins, W., Daskalakis, N., Dusinska, M., Eckhardt, S., Fuglestvedt, J. S., Harju, M., Heyes, C., Hodnebrog, Ø., Hao, J., Im, U., Kanakidou, M., Klimont, Z., Kupiainen, K., Law, K. S., Lund, M. T., Maas, R., MacIntosh, C. R., Myhre, G., Myriokefalitakis, S., Olivié, D., Quaas, J., Quennehen, B., Raut, J.-C., Rumbold, S. T., Samset, B. H., Schulz, M., Seland, Ø., Shine, K. P., Skeie, R. B., Wang, S., Yttri, K. E., and Zhu, T.: Evaluating the climate and air quality impacts of short-lived pollutants, Atmos. Chem. Phys., 15, 10529-10566, doi:10.5194/acp-15-10529-2015, 2015.

Taylor, J. W., Allan, J. D., Liu, D., Flynn, M., Weber, R., Zhang, X., Lefer, B. L., Grossberg, N., Flynn, J., and Coe, H.: Assessment of the sensitivity of core / shell parameters derived using the single-particle soot photometer to density and refractive index, Atmos. Meas. Tech., 8, 1701-1718, doi:10.5194/amt-81701-2015, 2015.

Thomas, J. L., Raut, J.-C., Law, K. S., Marelle, L., Ancellet, G., Ravetta, F., Fast, J. D., Pfister, G., Emmons, L. K., Diskin, G. S., Weinheimer, A., Roiger, A., and Schlager, H.: Pollution transport from North America to Greenland during summer 2008, Atmos. Chem. Phys., 13, 3825-3848, doi:10.5194/acp-13-38252013, 2013.

Wang, Q., Jacob, D. J., Fisher, J. A., Mao, J., Leibensperger, E. M., Carouge, C. C., Le Sager, P., Kondo, Y., Jimenez, J. L., Cubison, M. J., and Doherty, S. J.: Sources of carbonaceous aerosols and deposited black carbon in the Arctic in winter-spring: implications for radiative forcing, Atmos. Chem. Phys., 11, 1245312473, doi:10.5194/acp-11-12453-2011, 2011.

Warneke, C., Bahreini, R., Brioude, J., Brock, C. A., de Gouw, J. A., Fahey, D. W., Froyd, K. D., Holloway, J. S., Middlebrook, A., Miller, L., Montzka, S., Murphy, D. M., Peischl, J., Ryerson, T. B., Schwarz, J. P., Spackman, J. R., and Veres, P.: Biomass burning in Siberia and Kazakhstan as an important source for 
haze over the Alaskan Arctic in April 2008, Geophys. Res. Lett., 36, L02813, doi:10.1029/2008GL036194, 2009.

Wiedinmyer, C., Quayle, B., Geron, C., Belote, A., McKenzie, D., Zhang, X., O'Neill, S., Klos, K., and Wynne, K.: Estimating emissions from fires in North America for air quality modelling, Atmos. Environ., 40, 3419-3432, 2006.
Yttri, K. E., Lund Myhre, C., Eckhardt, S., Fiebig, M., Dye, C., Hirdman, D., Ström, J., Klimont, Z., and Stohl, A.: Quantifying black carbon from biomass burning by means of levoglucosan - a one-year time series at the Arctic observatory Zeppelin, Atmos. Chem. Phys., 14, 6427-6442, doi:10.5194/acp-14-64272014, 2014. 